PONTIFÍCIA UNIVERSIDADE CATÓLICA do RIO DE JANEIRO

\title{
FATORES QUE INFLUENCIAM A QUALIDADE DE VIDA NO TRABALHO DE MOTORISTAS DE ÔNIBUS URBANO NA CIDADE DO RIO DE
} JANEIRO

\author{
Pedro Victor C. Fernandes \\ trabalho de Conclusão de Curso
}

Centro de Ciências sociais - CCS

DePARTAMENTO de AdMINISTRAÇÃo

Graduação em Administração de Empresas 
Pedro Victor C. Fernandes

Fatores que influenciam a qualidade de vida no trabalho de motoristas de ônibus urbano na cidade do Rio de Janeiro

Trabalho de Conclusão de Curso

Trabalho de Conclusão de Curso, apresentado ao programa de graduação em Administração da PUC-Rio como requisito parcial para a obtenção do titulo de graduação em Administração.

Orientador:Jorge Luiz Cordeiro Paulo

Rio de Janeiro Novembro de 2016 


\section{Resumo}

C. Fernandes, Pedro Victor. Fatores que influenciam a qualidade de vida no trabalho de motoristas de ônibus urbano na cidade do Rio de Janeiro. Rio de Janeiro, 2016. 44 páginas. Trabalho de Conclusão de Curso - Departamento de Administração. Pontifícia Universidade Católica do Rio de Janeiro. Orientador: Jorge Luiz Cordeiro Paulo.

As péssimas condições de trabalho de motoristas de ônibus é um problema conhecido pela maioria da sociedade, e está presente em todos estados brasileiros. Como morador da cidade do Rio de Janeiro, foi feito esta pesquisa monográfica com o intuito de identificar as principais variáveis que afetam a Qualidade de Vida no Trabalho (QVT) dos motoristas de ônibus urbanos da cidade. Utilizando de teorias que tratam das conseqüências físicas e mentais aos quais os trabalhadores adquirem em detrimento do seu ambiente e atividade de trabalho, como a QVT e Higiene Ocupacional, pode-se compreender quais e como as variáveis afetam os trabalhadores dessa atividade profissional.

Palavras- chave:

Qualidade de Vida no Trabalho, Higiene Ocupacional, Motoristas de ônibus urbano, Cidade do Rio de Janeiro. 


\section{Abstract}

C. Fernandes, Pedro Victor. Factors influencing the quality of life in the work of urban bus drivers in the city of Rio de Janeiro. Rio de Janeiro, 2016.44 pages. Course Completion Work - Administration Department. Pontifical Catholic University of Rio de Janeiro. Advisor: Jorge Luiz Cordeiro Paulo

The poor working conditions of bus drivers is a problem known to most of society, and is present in all Brazilian states. As a resident of the city of Rio de Janeiro, I carried out this monographic research in order to identify the main variables that affect the quality of life at work (QLW) of urban bus drivers in the city. Using theories that deal with the physical and mental consequences to which workers acquire to the detriment of their environment and work activity, such as QLW and Occupational Hygiene, I was able to understand what and how the variables affect workers in this professional activity.

Key-words:

Quality of life in the workplace, occupational hygiene, Urban bus drivers, City of Rio de Janeiro 


\section{Agradecimentos}

Primeiramente gostaria de agradecer ao professor Jorge Luiz Cordeiro Paulo, que deu todo suporte, conselhos e metodologias para a realização desse trabalho de conclusão de curso.

Agradeço também, à minha namorada Ana Carolina, por toda a compreensão e ajuda para concluir o trabalho. 


\section{Sumário}

1 O tema e o problema de estudo 1

1.1. Introdução ao tema e ao problema do estudo 1

1.2. Objetivo do estudo 3

1.3. Objetivos intermediários do estudo 3

1.4. Delimitação e foco do estudo 3

1.5. Justificativa e relevância do estudo 3

2 Revisão de literatura 5

2.1. Conceituando Qualidade de Vida 5

2.2. Qualidade de Vida no Trabalho (QVT) 5

$\begin{array}{ll}\text { 2.2.1. Higiene Ocupacional } & 7\end{array}$

3 Métodos e procedimentos de coleta e de análise de dados do estudo 10

3.1. Etapas de coleta de dados 10

3.2. Fontes de informação selecionadas para coleta de dados 10

3.3. Procedimentos utilizados para a coleta de dados 11

3.4. Formas de tratamento e análise dos dados coletados 11

4 Apresentação e análise dos resultados $\quad 13$

4.1. Apresentação e comentários sobre os resultados 13

4.1.1. Higiene Ocupacional 15

4.1.2. Segurança 16

4.1.3. Praticas Trabalhistas das Empresas 17

4.1.4. Desgaste Físico e Mental 19

4.2. Análise dos resultados 20

5 Conclusão 25

5.1. Sugestões e recomendações para novos estudos 26

6 Referências Bibliográficas $\quad 27$ 


\section{Lista de Tabelas e Gráficos}

Tabela 1: Lista das 10 piores profissões para se trabalhar no Brasil 2

Tabela 2: Riscos Ambientais 9

Gráfico 1: Região de trabalho $\quad 11$

Gráfico 2: Idade dos Entrevistados $\quad 12$

Gráfico 3: Tempo de profissão 12

Gráfico 4: Problemas de Saúde $\quad 20$

Gráfico 5: Problemas de Insegurança Sofridos $\quad 21$

Gráfico 6: Suporte Médico $\quad 22$

Gráfico 7: Problemas no dia a dia de trabalho 23

\section{Apêndices:}

Apêndice A: Roteiro das entrevistas $\quad 25$

$\begin{array}{ll}\text { Apêndice B: Sínteses das entrevistas } & 27\end{array}$ 


\section{0 tema e o problema de estudo}

\subsection{Introdução ao tema e ao problema do estudo}

Um dos principais problemas enfrentados pela população que vive em grandes metrópoles, como a cidade do Rio de Janeiro, é o estresse causado pelas longas filas de automóveis, caminhões, motocicletas e ônibus que formam o trânsito pela cidade. Uma pesquisa recente (2015), feita pela Firjan (Federação das Indústrias do Estado do Rio de Janeiro), prevê que em 2016 a proporção será de 1 carro para cada 2 cariocas na cidade do Rio de Janeiro. Agora, imagine que em seu trabalho você tenha que enfrentar esse trânsito diariamente, 9 horas por dia, de segunda a sexta-feira. Pois esse é o trabalho de um motorista de Ônibus, que além da tensão causada pelo trânsito, enfrenta outros problemas que prejudicam não só a sua motivação no trabalho, mas, também, a própria qualidade de vida.

Em pesquisa de 2013, o website de busca de empregos adzuna.com.br, analisou mais de 2.000 profissões no Brasil e listou as 10 melhores e piores para se trabalhar. $\mathrm{Na}$ pesquisa atribuíram-se pontos em consideração a alguns fatores: Potencial financeiro (média salarial anual); Competitividade entre funcionários; Ambiente de trabalho; Demanda de mercado (prazos de entrega). O resultado das piores profissões para se trabalhar, no Brasil, pode ser visto na tabela 1 a seguir, onde a profissão de motorista de ônibus foi a pior dentre as 2.000 profissões analisadas, mesmo sendo sua média salarial anual (potencial financeiro) maior que outras profissões. A pontuação negativa atribuída aos motoristas de ônibus é significativamente maior que aquela associada ao segundo colocado (Entregadores). Segundo os pesquisadores, isto é decorrente do fato desses profissionais lidarem com prazos apertados, baixo potencial de aumento de salário e uma longa e cansativa jornada de trabalho. 
Tabela 1:

\begin{tabular}{|l|l|l|}
\hline \multicolumn{3}{|c|}{ PROFISSIONAIS COM AS PIORES ATIVIDADES } \\
\hline Atividade profissional & Média salarial anual & Pontuação \\
\hline Motoristas de ônibus & $\mathrm{R} \$ 20 \mathrm{mil}$ & -36 \\
\hline Entregadores & $\mathrm{R} \$ 12 \mathrm{mil}$ & -28 \\
\hline Assistentes de cozinha & $\mathrm{R} \$ 14 \mathrm{mil}$ & -28 \\
\hline Jornalistas & $\mathrm{R} \$ 20 \mathrm{mil}$ & -27 \\
\hline Policiais & $\mathrm{R} \$ 30 \mathrm{mil}$ & -26 \\
\hline Vendedores & $\mathrm{R} \$ 25 \mathrm{mil}$ & -23 \\
\hline Empregadas doméstica & $\mathrm{R} \$ 15 \mathrm{mil}$ & -23 \\
\hline Garçons & $\mathrm{R} \$ 14 \mathrm{mil}$ & -20 \\
\hline Assistentes sociais & $\mathrm{R} \$ 26 \mathrm{mil}$ & -20 \\
\hline Seguranças & $\mathrm{R} \$ 23 \mathrm{mil}$ & -8 \\
\hline
\end{tabular}

Fonte: http://classificados.folha.uol.com.br/empregos/2013/09/1340405-pesquisa-indica-as-10piores-profissoes-do-brasil-ser-motorista-lidera-ranking.shtml

Apesar de a pesquisa compreender diversas regiões do Brasil, e o presente trabalho se restringirà cidade do Rio de Janeiro, todo cidadão carioca sabe ou concorda que as condições de trabalho dessa classe profissional são precárias.

O estresse vivido por esses profissionais em seu ambiente de trabalho tem sido causa de afastamentos no estado do Rio de Janeiro. O Sindicato dos Rodoviários calculou que em março deste ano, existam 5.700 rodoviários afastados do trabalho por problemas psicológicos, psiquiátricos ou neurológicos em Niterói e São Gonçalo, o que corresponde a $30 \%$ do número de profissionais atuantes nestes municípios.Síndrome do pânico e estresse constante se destacam como causas de tratamentos neurológicos nesses profissionais.

Com base nesses dados, infere-se que o ambiente de trabalho do motorista de ônibus é extremamente prejudicial para a sua saúde, pois estão submetidos a várias condições adversas, como: a poluição causada pelos veículos automotivos e o calor e a trepidação do motor; tudo contribuindo para que sofra transtornos psiquiátricos, hipertensão ou problemas da coluna.

Além da exposição ao barulho, que segundo estudos da Abramet (Associação Brasileira de Medicina de Tráfego), os motoristas têm suportado volumes acima dos decibéis que a legislação determina para a exposição máxima ao barulho (85 decibéis), podemos listar a longa jornada de trabalho como fatores agravantes da baixa qualidade de vida constatada para esses profissionais.

Com prazos de chegada apertados e o trânsito do Rio de Janeiro aumentado a cada dia, as jornadas de trabalho podem ultrapassar as 10 horas diárias. Segundo Dirceu 
Rodrigues Alves, diretor da Associação Brasileira de Medicina de Tráfego (Abramet): "Por terem insalubridade, médicos, bancários e operadores de telemarketing cumprem jornada de apenas seis horas. Por que, então, motoristas de ônibus, que enfrentam insalubridade e periculosidade, vivem uma rotina penosa que pode chegar a 12 ou 13 horas de trabalho?".

Surge daí o interesse em investigar as seguintes questões: Quais são as principais variáveis que afetam a qualidade de vida dos motoristas de ônibus na cidade do Rio de Janeiro? Que medidas as empresas de ônibus podem tomar para reduzir os prejuízos resultantes das varáveis encontradas?

\subsection{Objetivo do estudo}

A partir dos questionamentos acima, o objetivo geral deste estudo consiste em: Identificar as três principais variáveis que afetam a qualidade de vida no trabalho dos motoristas de ônibus da cidade do Rio de Janeiro, e propor soluções para atenuá-las.

\subsection{Objetivos intermediários do estudo}

Destacam-se como objetivos intermediários deste estudo:

a) Analisar teorias sobre Qualidade de Vida no Trabalho (QVT);

b) Analisar práticas adotadas pelas empresas de ônibus da cidade do Rio de Janeiro em relação aos seus motoristas;

c) Selecionar hipóteses relevantes para se analisar influencias sobre a qualidade de vida dos motoristas de ônibus.

\subsection{Delimitação e foco do estudo}

O estudo foi realizado no mês de novembro de 2016, com base na rotina dos motoristas de ônibus urbano na cidade do Rio de Janeiro, tendo como foco as práticas que as empresas de ônibus da referida cidade adotam em relação aos seus motoristas, no que diz respeito à Qualidade de Vida no Trabalho.

Por problemas relacionados à falta de tempo e acessibilidade, a região do Centro da cidade do Rio de Janeiro não pode ser contemplada nesse estudo.

\subsection{Justificativa e relevância do estudo}

A escolha deste tema visa contribuir para a compreensão das condições de trabalho dos motoristas de ônibus da cidade do Rio de Janeiro e respectivos condicionantes da QVT. 
O estudo tem relevância para que os passageiros de ônibus possam compreender melhor a realidade que um motorista de ônibus enfrenta numa metrópole como o Rio de Janeiro.

Além disso, poderá ajudar as empresas de ônibus a tomarem conhecimento da responsabilidade que possuem com a qualidade de vida de seus motoristas, na expectativa de propor soluções que possam melhorar a QVT dos motoristas de ônibus. 


\section{Revisão de literatura}

\subsection{Conceituando Qualidade de Vida}

Para podermos discursar sobre QVT, devemos primeiro definir o conceito de Qualidade de Vida para o ser humano, por antecedê-lo. Souza e Guimarães (1999), afirmam que os cientistas sociais, filósofos e políticos foram os primeiros a se interessarem pelos conceitos de Qualidade de Vida e Padrão de Vida.

Já Wilheim e Deak (1970), definiram Qualidade de Vida como a sensação que o individuo tem do seu próprio bem-estar do indivíduo. Segundo os autores, esta sensação é proporcionada pela satisfação de condições objetivas (renda, emprego, imóveis, qualidade de habitação) e subjetivas (segurança, privacidade, reconhecimento, afeto).

Essa definição compreende que qualidade de vida de uma pessoa, depende da sensação de satisfação gerada por fatores objetivos, mensuráveis e concretos e fatores subjetivos, relacionados ao que é abstrato, como os sentimentos humanos e experiências vividas.

A Organização Mundial de Saúde (OMS), por sua vez, reuniu especialistas de várias partes do mundo, que definiram qualidade de vida como "a percepção do indivíduo de sua posição na vida no contexto da cultura e sistema de valores nos quais ele vive e em relação aos seus objetivos, expectativas, padrões e preocupações ". (The WHOQOL Group, 1997, p.1).

Para a referência deste trabalho, será utilizado o conceito de Qualidade de Vida proposto pelos autores Wilheim e Deak (1970). A definição proposta se aproxima bastante do conceito que será abordado no próximo tópico, Qualidade de Vida no Trabalho (QVT).

\subsection{Qualidade de Vida no Trabalho (QVT)}

Segundo Oliveira e França (2005) a internacionalização dos mercados, ocasionou um aumento na pressão por produtividade e da capacidade competitiva que as empresas sofrem. Em consequência, as empresas passaram a pressionar mais os empregados, cobrando uma maior produtividade, iniciativa, conhecimento e inovação. Os efeitos da mudança no ambiente de trabalho são sentidos pelos empregados, pois se exige muito deles. Um dos sinais desse aumento na cobrança foi o aparecimento de problemas de saúde decorrentes da atividade profissional. O aparecimento, cada vez maior, dos 
problemas de saúde relacionados ao trabalho, fez com que a Qualidade de Vida no Trabalho (QVT) passasse a ser uma preocupação cada vez mais presente nas organizações.

A QVT deve ser uma preocupação tanto dos empregados quanto dos empregadores. Diversos autores dissertaram sobre qual é a definição mais abrangente para esse termo e suas diferentes interpretações.

Para Chiavenato (2004, p. 448), "[...] a organização que quiser atender bem o cliente externo, ela não poderá se esquecer de atender bem o cliente interno." Assim como o trecho destacado do Chiavenato e de acordo com a maioria dos conceitos sobre QVT, o bem estar dos funcionários é o objetivo principal. O empregado precisa se sentir seguro e tranquilo durante o desempenho das suas atividades.

Quirino e Xavier (1987) definem QVT como uma ligação entre as condições de trabalho dos empregados e sua satisfação em relação ao cargo e trabalho humanizado.Os autores introduzem conceitos importantes como as condições de trabalho e trabalho humanizado.

Ainda segundo Quirino e Xavier (1987), a QVT pode ser avaliada de duas maneiras dentro de uma organização: de maneira objetiva, mensurando as condições objetivas (disponibilidade de material, suporte tecnológico, política de remuneração, espaço físico, entre outras); ou de maneira subjetiva que apuraria a percepção dos trabalhadores sobre as condições objetivas, avaliando-as em satisfatórias ou não.

A autora França (1997), esclarece que a QVT se origina da medicina psicossomática, e que esta propõe uma visão sistêmica do ser humano, em oposição à abordagem cartesiana que o divide em partes. E conclui, ao afirmar que:

No campo do trabalho esta abordagem pode ser associada à ética da condição humana. Esta ética busca desde a identificação, eliminação, neutralização ou controle de riscos ocupacionais observáveis no ambiente físico, padrões de relações de trabalho, carga física e mental requerida para cada atividade, implicações políticas e ideológicas, dinâmica da liderança empresarial e do poder formal até o significado do trabalho em si, relacionamento e satisfação no trabalho. (FRANÇA, 1997, p. 80)

França, tem uma visão psicossomática em relação ao modo de se olhar para empresa. Nessa visão, para um bom funcionamento da organização, todas as áreas e pessoas devem ser tratadas como um todo e não dividida em partes. Ela também diz que os empregadores tem o dever de reduzir ao máximo os ricos ocupacionais inerente ao trabalho para que o empregado tenha uma melhor QVT. Será em cima dessa definição do conceito de QVT que este trabalho fará referência.

Os autores Gonçalves A., Gutierrez G. L. e Vilarta R. (2005) falam sobre o papel dos empregadores para com a QVT dentro da empresa. A política da QVT visa promover 
condições adequadas no local de trabalho, através do gerenciamento correto dos diferentes domínios no campo de pesquisa e intervenção. Este processo depende da articulação entre práticas tradicionais das políticas de Relações Humanas e Medicina do Trabalho na empresa, como:

- ações dirigidas ao bem estar do trabalhador

- medicina do trabalho

- comissão interna de prevenção de acidentes (CIPA)

- treinamentos específicos

- Entre outras...

A atividade profissional é uma variável importante na causalidade de muitas doenças. É papel dos empregadores reduzir ao máximo os ricos ocupacionais inerente ao trabalho. Foi dessa preocupação que outro conceito importante relacionado à QVT foi criado, a Higiene Ocupacional.

\subsubsection{Higiene Ocupacional}

A American Industrial Hygiene Association (AlHA - Associação Americana de Higiene Industrial, 2012), define higiene ocupacional como a ciência e arte dedicadas ao reconhecimento, prevenção, avaliação e controle dos fatores ambientais, tensões emanadas ou provocadas pelo local de trabalho que podem ocasionar enfermidades, afetar a saúde e o bem-estar ou desconforto significativo entre os trabalhadores ou os cidadãos da comunidade.

Higiene Ocupacional é uma ciência do ramo da segurança e medicina do trabalho, responsável pelo estudo dos possíveis prejuízos à saúde e à integridade dos trabalhadores. Para isso antecipam, reconhecem, controlam e avaliam os riscos ocupacionais presentes no ambiente de trabalho. Segundo a International Occupational Hygiene Association (IOHA Associação Internacional de Higiene Ocupacional, 2012), é a antecipação, reconhecimento, avaliação e controle de riscos para a saúde, no ambiente de trabalho, com o objetivo de proteger a integridade física e o bem-estar do trabalhador e salvaguardar a comunidade em geral.

As definições sobre higiene podem conter variações, mas todas compreendem o mesmo objetivo que é proteger e promover a saúde, o bem-estar dos trabalhadores como no meio ambiente em geral, através de ações preventivas no ambiente de trabalho.

Os agentes ou riscos ambientais são elementos ou substâncias presentes em diversos ambientes, que acima dos limites de tolerância podem ocasionar danos à saúde 
das pessoas. Pode-se dividir os riscos presentes no ambiente de trabalho em grupos. São eles:

- Riscos físicos: Representam diversas formas de energia que podem estar presentes em um ambiente de trabalho, com uma quantidade superior àquela que o organismo é capaz de suportar.

- Riscos químicos: são substâncias, elementos, compostos ou resíduos químicos que podem vir a contaminar o indivíduo ou o ar do ambiente de trabalho.

- Riscos biológicos: são micro-organismos vivos, capazes de contaminar os ambientes ocupacionais e afetar a saúde do trabalhador.

- Riscos ergonômicos: são fatores no ambiente de trabalho que podem gerar distúrbios psicológicos e fisiológicos. Eles podem causar sérios problemas à saúde do trabalhador, pois produzem alterações no organismo e estado emocional, comprometendo sua produtividade, saúde e segurança.

- Riscos de Acidentes: Estão relacionados às atividades que envolvam equipamentos, máquinas ou outras situações que põem em risco a integridade física dos empregados. Eles podem causar uma lesão e ocorrência de acidentes de trabalho.

Cada um destes riscos representa as consequências fisiológicas que podem provocar. A Tabela 2 abaixo mostra os tipos de riscos, seus respectivos grupos e agentes: 
Tabela 2:

\begin{tabular}{|c|c|c|c|c|}
\hline \multicolumn{5}{|c|}{ RISCOS AMBIENTAIS } \\
\hline $\begin{array}{l}\text { GRUPO } 1 \\
\text { VERDE }\end{array}$ & $\begin{array}{c}\text { GRUPO } 2 \\
\text { VERMELHO }\end{array}$ & $\begin{array}{l}\text { GRUPO } 3 \\
\text { MARROM }\end{array}$ & GRUPO 4 AMARELO & GRUPO 5 AZUL \\
\hline RIScos Físıcos & $\begin{array}{c}\text { RISCOS } \\
\text { QuímICos } \\
\end{array}$ & \begin{tabular}{|c|} 
RISCOS \\
BIOLóGICOS \\
\end{tabular} & $\begin{array}{c}\text { RISCOS } \\
\text { ERGONÔMICOS }\end{array}$ & RISCOS ACIDENTES \\
\hline Ruídos & Poeiras & Vírus & Esforço físico intenso & \begin{tabular}{|l|} 
Arranjo físico \\
inadequado
\end{tabular} \\
\hline Vibrações & Fumos & Bactérias & $\begin{array}{l}\text { Levantamento e } \\
\text { transporte manual } \\
\text { de peso }\end{array}$ & $\begin{array}{l}\text { Máquinas e } \\
\text { equipamentos sem } \\
\text { proteção }\end{array}$ \\
\hline $\begin{array}{l}\text { Radiações } \\
\text { ionizantes }\end{array}$ & Névoas & Protozoários & $\begin{array}{l}\text { Exigencia de postura } \\
\text { inadequada }\end{array}$ & \begin{tabular}{|l} 
Ferramentas \\
inadequadas ou \\
defeituosas
\end{tabular} \\
\hline $\begin{array}{l}\text { Radiações não } \\
\text { ionizantes } \\
\end{array}$ & Neblinas & Fungos & \begin{tabular}{|l|}
$\begin{array}{l}\text { Controle rígido de } \\
\text { produtividade }\end{array}$ \\
\end{tabular} & $\begin{array}{l}\text { Iluminação } \\
\text { inadequada }\end{array}$ \\
\hline Frio & Gases & Parasitas & $\begin{array}{l}\text { Imposição de ritmos } \\
\text { excessivos }\end{array}$ & Eletricidade \\
\hline Calor & Vapores & Bacilos & $\begin{array}{l}\text { Trabalho em turno e } \\
\text { noturno }\end{array}$ & $\begin{array}{l}\text { Probabilidade de } \\
\text { incendio ou } \\
\text { explosão }\end{array}$ \\
\hline $\begin{array}{l}\text { Pressões } \\
\text { anormais }\end{array}$ & $\begin{array}{l}\text { Substâncias } \\
\text { ou produtos } \\
\text { quimicos em } \\
\text { geral }\end{array}$ & & $\begin{array}{l}\text { Jornadas de trabalho } \\
\text { prolongadas }\end{array}$ & $\begin{array}{l}\text { Armazenamento } \\
\text { inadequado }\end{array}$ \\
\hline \multirow[t]{2}{*}{ Umidade } & & & \begin{tabular}{|l|}
$\begin{array}{l}\text { Monotonia e } \\
\text { repetitividade }\end{array}$ \\
\end{tabular} & \begin{tabular}{|l} 
Animais \\
peçonhentos
\end{tabular} \\
\hline & & & $\begin{array}{l}\text { Outras situações } \\
\text { causadoras de stress } \\
\text { físico e/ou psíquico }\end{array}$ & \\
\hline
\end{tabular}

Fonte: http://www.cursosegurancadotrabalho.net/2013/08/Classificacao-dos-Riscos-Ambientais-emgrupos-de-Cores.html

Uma vez que os riscos presentes no ambiente do trabalho foram identificados e medidos, as empresas têm o papel de executar medidas que eliminem, reduzam ou neutralizem as exposições. As medidas de controle vão depender dos tipos de riscos levantados, e essas medidas podem incluir:

- Estabelecimento de valores limites, métodos de amostragem, medição e avaliação;

- Medidas de proteção coletiva;

- Medidas de proteção pessoal, quando não for possível evitar por outros meios;

- Registro de dados relativos a níveis de exposição, trabalhadores expostos e resultados de vigilância da saúde.

As empresas, portanto, têm o papel de reduzir ao máximo os riscos presentes no ambiente de trabalho, como forma de melhorar a qualidade de vida de seus funcionários. 


\section{Métodos e procedimentos de coleta e de análise de dados do estudo}

Este capítulo pretende informar sobre as diversas decisões acerca da forma como este estudo foi realizado. Está dividido em cinco seções que informam, respectivamente, sobre a coleta de dados, o universo do estudo, os procedimentos utilizados para a coleta de dados, os procedimentos de tratamento e análise dos dados coletados e, por fim, sobre limitações decorrentes de possíveis repercussões que as decisões sobre como realizar o estudo impuseram aos resultados assim obtidos.

\subsection{Etapas de coleta de dados}

Para a realização da coleta de dados foi feito uma pesquisa qualitativa, por meio de entrevistas. O roteiro da entrevista foi feito para compreender as diferentes variáveis que influenciam a qualidade de vida no trabalho dos motoristas de ônibus urbano da cidade do Rio de Janeiro. As perguntas abordaram questões como: Segurança no trabalho; Saúde ocupacional; Práticas trabalhistas, por parte da empresa; Jornada de trabalho, conforme pode ser visto no apêndice 1 . No total foram coletados 25 entrevistas com motoristas de ônibus da cidade do Rio de Janeiro.

\subsection{Fontes de informação selecionadas para coleta de dados}

As fontes de informação selecionadas foram motoristas de ônibus urbano, que trafegam pelas regiões (zonas sul, oeste e norte) do Rio de Janeiro, com exceção do centro. Como algumas regiões da zona oeste e da zona norte apresentam semelhanças em relação à insegurança, foi buscado um contraponto com a região sul, que é considerada mais segura, em termos de assaltos a ônibus e tiroteios.

Como os motoristas trafegam em mais de uma região por dia, foram procurados respondentes em um local que tivesse diferentes empresas e com destinos variados. Desta forma, foi possível ter acesso a respondentes que trafegam pelas diversas áreas do Rio de Janeiro. O local escolhido para as entrevistas foi o Terminal Alvorada, localizado na região Oeste, na Barra da Tijuca. 
Durante as entrevistas, fez-se um esforço para equilibrar o tempo de profissão dos respondentes e as regiões por onde trafegam. Para isso, após ter feito, aproximadamente, metade das entrevistas, era perguntado antecipadamente ao entrevistado a região por onde trafega e tempo de profissão. Desta forma, tentou-se equilibrar a amostra, buscando respondentes que representassem as variáveis com menos respostas.

\subsection{Procedimentos utilizados para a coleta de dados}

O meio de coleta de dados foi a entrevista, porque dá a possibilidade de o entrevistado fornecer informações mais detalhadas, e dar respostas que vão além do que foi perguntado. A entrevista também permite um contato visual, que pode ser levado em conta no momento das análises.

A pesquisa de campo foi realizada no segundo semestre de 2016, através do roteiro, contendo oito perguntas abertas. As entrevistas com os motoristas foram realizadas no Terminal Alvorada, localizado na Barra da Tijuca, pois este terminal é um ambiente de escala, onde os motoristas têm um intervalo para descanso e há motoristas que trafegam pelas quatro zonas da cidade do Rio de Janeiro.

Para que a entrevista ficasse mais rápida e dinâmica, foi utilizado um gravador de voz para gravar as entrevistas. Posteriormente, as 25 entrevistas foram transcritas para o computador, para serem sintetizadas e analisadas.

\subsection{Formas de tratamento e análise dos dados coletados}

Após a coleta dos dados obtidos pela pesquisa qualitativa, eles foram mensurados e analisados de forma a responder os objetivos propostos. Os dados foram ser analisados de forma qualitativa, analisando os pensamentos dos entrevistados, que foram livremente ditos, sobre as perguntas feitas nas entrevistas.

Ao final da apuração das análises qualitativas, os pensamentos e opiniões que mais apareciam nas respostas foram quantificados. Como as respostas eram similares, planilhas foram feitas para quantificar, através de porcentagem, os aspectos que se assemelhavam.

As perguntas e respostas analisadas foram divididas de acordo com o tema teórico que abordavam. Desta forma, foi possível extrair conclusões pertinentes ao objetivo que o estudo propôs. 


\subsection{Limitações do estudo}

Devido à falta de tempo e de acessibilidade, não foi possível coletar entrevistas com motoristas que transitam pelo Centro do Rio de Janeiro. Então, essa região fui excluída do trabalho, contemplando somente as regiões Oeste, Sul e Norte.

Apesar de achar que alguns motoristas se sentiram receosos de fazer a entrevista, por acreditar que era um "teste" da empresa em que trabalham, o fato da entrevista ter sido feita em um terminal rodoviário ajudou a manter fresca a memória deles em relação aos problemas sofridos.

A região Norte apresentou uma quantidade de entrevistados menor que a das outras regiões. Este fato ocorreu por conta da dificuldade de encontrar motoristas desta região, e pela falta de tempo de coletar mais entrevistas. Diversos motoristas fazem mais de uma região, então muitos saíam da região Oeste e iam para outras regiões. Isso fez com que a região Oeste tivesse um numero maior de entrevistados, 15 , enquanto a região Sul obteve 12 e a Norte 6. 


\section{Apresentação e análise dos resultados}

Neste capitulo, os resultados obtidos pela pesquisa de campo serão apresentados e analisados. A partir da síntese das 25 entrevistas realizadas e dos referenciais teóricos, pode-se dividir as perguntas, em subtítulos que envolvem as variáveis que afetam os motoristas. Tanto as sínteses como o roteiro das entrevistas estão nos apêndices.

\subsection{Apresentação e comentários sobre os resultados}

Antes de responderem às perguntas, foi identificado o perfil dos respondentes.

Em relação à região em que o motorista trafega, foram contempladas as 3 zonas do Rio de Janeiro abordadas no trabalho (regiões Sul, Norte e Oeste), conforme mostra o gráfico 1 abaixo. O número de entrevistados que trafega na região Oeste foi de 15 , na região Sul foi de 12 e a Norte com 6.

Gráfico1

\section{Região de trabalho}

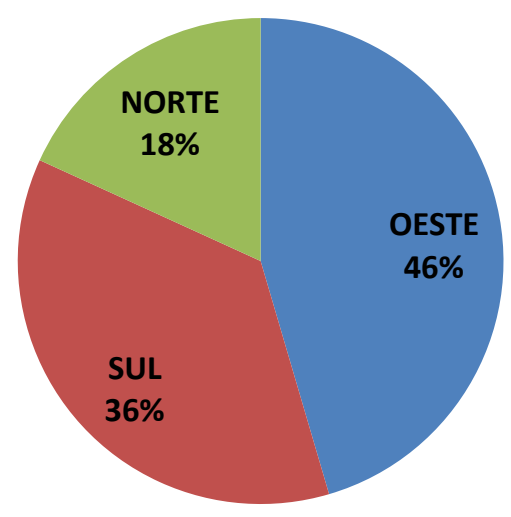

- OESTE

- SUL

NORTE

Como muitos motoristas trafegam por mais de uma região, dentro da cidade do Rio de Janeiro, o número de regiões foi maior que o número de entrevistados. 
Ao fazer as entrevistas, foram encontrados poucos motoristas com menos de 30 anos de idade, este fato pode ocorrer por conta que as empresas não gostam de contratar motoristas com pouco tempo na direção. A média de idade de todos os entrevistados foi de 42,7 anos, e o gráfico 2 abaixo mostra o numero de entrevistado de acordo com faixa etária:

Gráfico 2

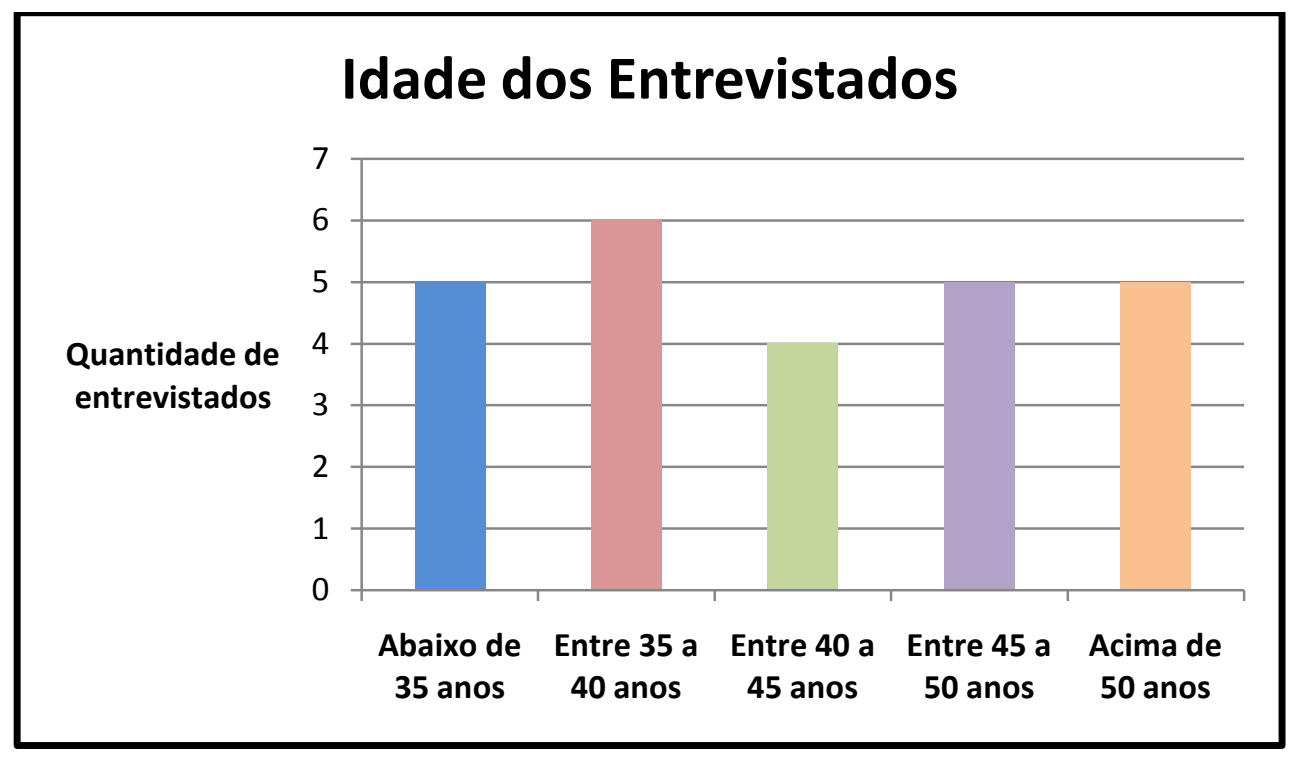

A variável tempo de profissão é muito importante, pois os motoristas que já têm anos de profissão, têm opiniões e análises que só podem ser observadas com o passar do tempo. A média do tempo de trabalho dos entrevistados foi de 8,8 anos. O gráfico 3 abaixo mostra a quantidade de entrevistados em relação ao tempo na profissão de motorista de ônibus, dividido em faixas:

Gráfico 3

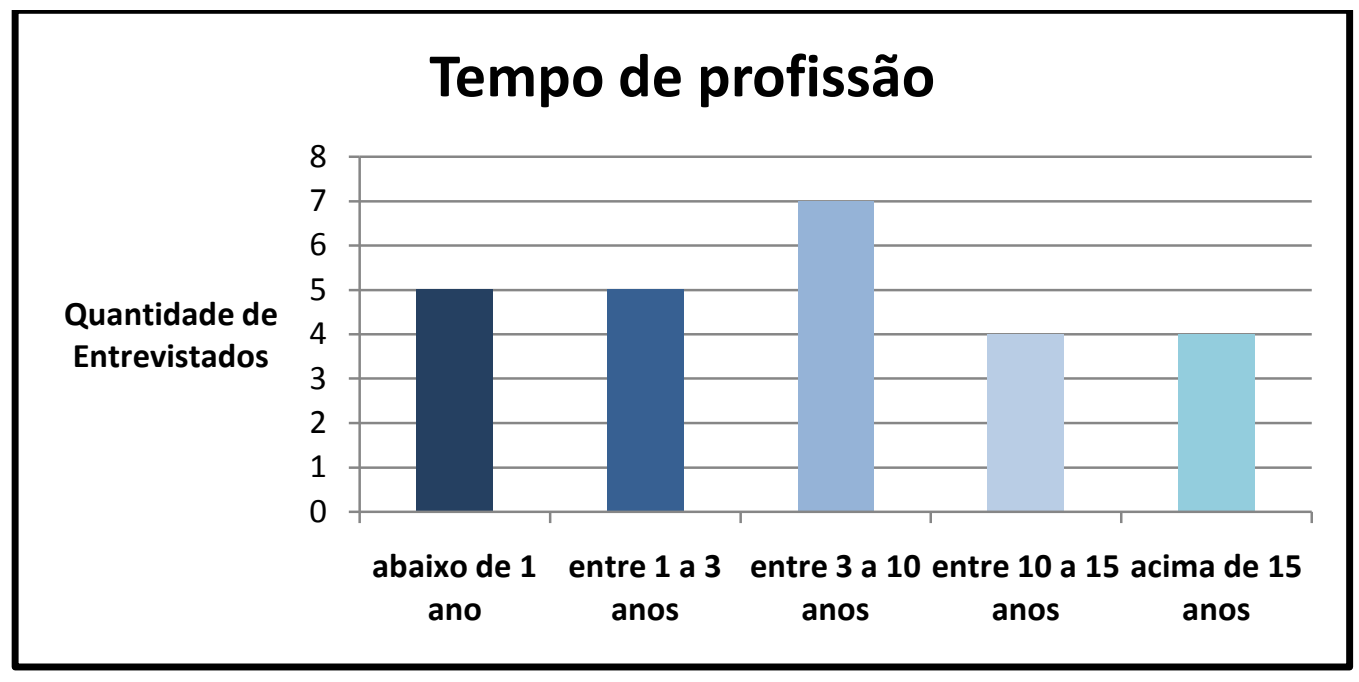


Os resultados foram apurados de acordo com o tema referente a cada pergunta. Cada tema corresponderá à análise de determinadas perguntas, de acordo com o critério a ser observado.

A pergunta 8 foi analisada em todos os tópicos abordados, porque é uma pergunta aberta, onde o entrevistado poderia apresentar uma informação importante para diversas variáveis.

\subsubsection{Higiene Ocupacional}

Sobre este tema, serão apuradas as respostas das perguntas 5, 7 e 8, de acordo com o roteiro. Neste tópico, o critério de avaliação levará em conta as respostas relacionadas a: Saúde dos motoristas; Práticas adotadas pelas empresas para diminuir os problemas de saúde; Tempo de profissão dos entrevistados. O tempo de profissão é uma variável importante, pois os problemas de saúde aparecem com o passar dos anos, com o desgaste da profissão.

A Higiene ocupacional é um termo relacionado a problemas de saúde que foram causados por conta da atividade da profissão. $60 \%$ dos entrevistados disseram não sofrer com esse tipo de problema, mas entre os que responderam que não sofrem, $60 \%$ tentam se prevenir. Os tipos de prevenção citados foram: Boa alimentação; Exercícios físicos; Trabalhar em uma boa postura, para evitar problemas de coluna; Procurar não se estressar com passageiros e motoristas; Ter horas de sono suficiente.

Entre os respondentes que disseram sofrer com esse tipo de problema, $40 \%$ disseram sofrer com problemas de coluna, $40 \%$ com estresse e $20 \%$ com perda de audição. Tanto o problema de coluna, quanto a perda de audição, são problemas causados pela exposição demasiada aos agentes dos ricos físicos (Grupo 1). De acordo com a teoria abordada no capitulo dois sobre Riscos Ambientais, os ricos físicos: "Representam diversas formas de energia que podem estar presentes em um ambiente de trabalho, com uma quantidade superior àquela que o organismo é capaz de suportar ".

O problema relacionado à coluna foi um dos mais citados, inclusive entre os entrevistados que disseram não sofrer com esse problema: "Tem gente ai que tem problema de hérnia, tem problema na coluna. Mas eu ainda não tive nenhum problema, sou novo ainda.", "sei que a profissão causa muito problema de coluna e procuro me cuidar ", "É muito comum em motoristas de ônibus problemas sérios de coluna “.

Os problemas relacionados ao estresse, também foi citado entre os que disseram não sofrer com esse tipo de problema: "mas tenho muitos colegas que tem problemas, 
nervosismo“. O problema de estresse é um agente dos Riscos Ergonômicos (Grupo 4), pois afeta a saúde mental do trabalhador.

Outra análise importante de se fazer é relacionar o tempo de profissão com os problemas de saúde causados pelo trabalho. Dos entrevistados que disseram sofrer com problemas de saúde, $80 \%$ tinham, pelo menos, 5 anos de profissão. Enquanto os que disseram não sofrer com problemas de saúde, 67\% não tinha completado 5 anos de profissão. Essa análise mostra que quanto maior o tempo de profissão, mais propenso a problemas de saúde ele estará.

De acordo com a teoria da Higiene Ocupacional, ao ser identificado e medido os riscos, as empresas devem reduzir, eliminar ou neutralizar esses riscos. Perguntados sobre como as empresas atuam para diminuir os problemas causados por eles no seu ambiente de trabalho, apenas um entrevistado relatou que a empresa paga integralmente o plano de saúde e seguro de vida, representando apenas $4 \%$ do total de entrevistados. Algumas empresas dividem o plano de saúde com o funcionário e fazem exames periódicos, totalizando $44 \%$ dos entrevistados. E $48 \%$ disseram que a empresa não oferece nenhum tipo de suporte médico. Enquanto os outros 4\% não souberam responder. Essa análise mostra o descaso das empresas de ônibus em relação à saúde de seus funcionários.

Alguns entrevistados ao responder a pergunta 8, relataram como melhoria, 0 fornecimento de plano de saúde e a diminuição do barulho feito pelo motor dos ônibus.

\subsubsection{Segurança}

Neste tópico, serão apuradas as respostas das perguntas 4 e 8 , de acordo com 0 roteiro. O critério de avaliação levará em conta os problemas relacionados à segurança no trabalho. Além da análise das perguntas, outra variável importante é a região por onde o motorista trafega, já que em muitas respostas a periculosidade da região está totalmente relacionada com a insegurança.

A segurança no ambiente de trabalho é uma das varáveis que mais afeta o cotidiano de trabalho. A segurança do trabalhador está totalmente ligada com o seu bem-estar, pois o conceito de QVT diz que o empregado precisa se sentir seguro e tranquilo durante o desempenho das suas atividades

Na pesquisa realizada, $68 \%$ dos entrevistados disseram ter sofrido algum tipo de risco à sua vida, no ambiente de trabalho. Entre os riscos sofridos por esses motoristas, $65 \%$ foram assaltados a mão armada, $24 \%$ sofreram agressão de passageiros e $12 \%$ tiveram problema de colisão com outros automóveis. Esses números mostram que há insegurança, pois $84 \%$ de todos os entrevistados relataram não se sentir seguro quando estão trabalhando. 
Uma variável que influencia para a questão de insegurança é a região por onde o motorista trafega. Muitos motoristas mencionaram que há regiões com maior índice de violência, como a Cidade de Deus e o morro do Borel. Um motorista relatou as dificuldades de dirigir pela Cidade de Deus: "eu trabalho dentro da Cidade de Deus e às vezes tem tiroteio lá. Quem conhece a linha já fica esperto, quem não conhece se joga no chão, ontem mesmo teve tiroteio por lá“.

A questão da segurança é um problema não só da profissão de motoristas de ônibus, mas de todos os moradores da cidade do Rio de Janeiro. Os problemas com assaltos e tiroteios são rotina para quem transita pela cidade, como disse um dos entrevistados: "Em relação a assalto, tudo pode acontecer, mesmo em uma condução de ônibus, ou na rua, em qualquer lugar. A gente está favorável a isso“.

Não é de hoje que os cariocas sofrem com o problema da insegurança na cidade, mas ainda pode piorar a situação. Segundo o Instituto de Segurança Pública (ISP), o numero de roubos de rua (somando-se os roubos a pedestres, roubos de aparelho celular e roubo em coletivo), no acumulado de janeiro a abril de 2016, teve um aumento de $23,7 \%$ em relação ao mesmo período de 2015 (31.083 em 2015 - 38.461 em 2016). As reclamações com a insegurança tendem a aumentar, tanto para a classe dos motoristas de ônibus, quanto para os cidadãos cariocas em geral.

Muitos entrevistados destacaram a segurança como uma das melhorias que poderiam ser feitas para tornar a rotina de trabalho menos estressante. Dentre as medidas que foram mencionadas para melhorar a segurança, foram citados: $A$ utilização do bilhete único, pois como eles trabalham com muito dinheiro dentro do ônibus aumenta o risco de assaltos; $A$ volta dos cobradores, pois gera uma sensação de proteção contra assaltos; Serem mais respeitados pelos passageiros.

\subsubsection{Praticas Trabalhistas das Empresas}

Sobre as práticas trabalhistas das empresas de ônibus, serão analisadas as respostas das perguntas 1, 6 e 8 . O critério de avaliação levará em conta a sobrecarga de funções dos motoristas e se eles consideram seus direitos trabalhistas respeitados.

As empresas de ônibus têm sua responsabilidade para a qualidade de vida no trabalho dos motoristas. Segundo a Rio Ônibus (Associação das empresas de transporte), o motorista só pode fazer dupla função nas linhas que têm $70 \%$ ou mais das passagens pagas com bilhete eletrônico. Com o aumento da utilização do Rio Card, a profissão de cobrador vem sendo extinta no município do Rio de Janeiro. $77,21 \%$ da frota não utilizam mais os cobradores. 
Já na pesquisa do trabalho, 96\% dos entrevistados disseram realizar a função de motorista e cobrador, e foi um dos motivos de mais críticas em relação ao estresse no trabalho. A grande maioria, $88 \%$, se diz sobrecarregado por conta da dupla função: "Sinto muito sobrecarregado mesmo, tem que olhar retrovisor, dirigir, dar informação, saber lugar de tudo e ainda receber o dinheiro".

Perguntados se consideram que seus direitos trabalhistas são respeitados, 64\% disseram que não. Entre os que não consideram 56\% reclamaram que, além de ser estressante ter que dirigir e se preocupar com o troco, eles não recebem a mais por conta disso: "o fato de ser motorista e cobrador, eles pagam só 7 reais a mais pra gente por isso ". Outros direitos que foram citados como não respeitados: Baixo valor do vale alimentação; Não pagamento de horas extras; Não depositam o FGTS.

Não foi só na pesquisa que os dados apontam um descaso das empresas com os motoristas. Em uma matéria do website diário do transporte, escrito pelo jornalista da rádio CBN, Adamo Bazine, especializado em transportes, é mostrado o desrespeito das empresas de ônibus com as legislações trabalhistas. A matéria apresenta um levantamento do Ministério do Trabalho no Rio de Janeiro, realizado em maio de 2016, relatando que todas as empresas analisadas não recolhem o FGTS de maneira correta e falham no pagamento de indenizações por rescisão de contrato de trabalho. O levantamento também destacou as longas jornadas de trabalho, que chegam de 10 a 12 horas. Em relação à dupla função, a superintendência defende que seja revista, pois foi comprovado o desgaste dos trabalhadores e prejuízos à saúde, segundo os auditores.

Pelas análises feitas na pesquisa do trabalho, a questão da dupla função se destacou como a mais desgastante. A pergunta 8 , onde o entrevistado podia dizer o que mais 0 incomoda, o problema mais citado foi novamente relacionado à dupla função. $44 \%$ dos entrevistados pediram a volta dos cobradores para tornar sua rotina de trabalho menos estressante.

De acordo com a QVT, as empresas têm o papel de promover condições adequadas no local de trabalho. Olhando os pontos analisados, podemos perceber que as empresas não estão tomando as medidas necessárias, como: Ações dirigidas ao bem estar do trabalhador; Medicina do trabalho; Treinamentos específicos; entre outros. Além de não tomarem medidas preventivas, nem o "básico" que seria o pagamento correto do FGTS, eles estão fazendo. 


\subsubsection{Desgaste Físico e Mental}

Neste tópico serão analisadas as respostas referentes às perguntas 2,3 e 8 . O critério de avaliação levará em conta a média de horas trabalhadas por dia e os problemas enfrentados por eles diariamente no seu ambiente de trabalho.

A carga horária de trabalho de um motorista de ônibus são 7 horas, mais uma hora de almoço, mas praticamente todos fazem horas extras. Entre os entrevistados, a maior média relatada foi de 12 horas, dando um total de 5 horas extras em um dia. A média de todos os entrevistados foi de 9 horas.

A longa jornada de trabalho é um problema ligado a uma má gestão da QVT na empresa. Este problema se enquadra nas ações preventivas relacionadas à fadiga administrativa e sofrimento organizacional. Além disso, as longas jornadas de trabalho se enquadram no risco ambiental ergonômico (grupo 4), por interferir nas características psicofislológicas do trabalhador, causando desconforto ou afetando sua saúde.

Sobre a pergunta 3 , vide roteiro em anexo, os problemas mais citados foram Problemas relacionados a passageiros (passageiros estressados, mal educados ou que não querem pagar), Transito intenso e Motoristas imprudentes.

Os problemas relacionados a passageiros foi a mais citada, obtendo $64 \%$ de respostas entre os que disseram sofrer com problemas diários. A relação passageiro e motorista é motivo de muito estresse para os motoristas de ônibus: "às vezes tem passageiro que entra com estresse dentro do carro, e querem descontar tudo na pessoa".

Trânsito intenso e motoristas imprudentes representaram a soma de $54 \%, 27 \%$ cada um, dos que disseram sofrer com algum problema no dia a dia de trabalho.. O trânsito intenso reflete muito no aumento da carga horária, deixando o trabalho mais cansativo e estressante. Enquanto motoristas imprudentes aumentam os riscos de batidas e demandam uma maior atenção do motorista para evitá-las, aumentando o estresse relacionado ao trabalho: "O ônibus pesa 10 toneladas, o carro pequeno entra na frente e freia bruscamente, você tem que levar no "breck" (seria a força ao pisar no freio) 20 toneladas.... Essas questões colocam as vidas das pessoas em risco, isso seria uma falta de educação no Trânsito".

Sobre a pergunta 8 , vide roteiro em anexo, 36\% dos entrevistados que propuseram melhorias relacionadas aos problemas desse tópico, desejam uma sociedade mais educada, para tornar sua rotina de trabalho menos estressante: "Ser mais respeitado por todos, principalmente passageiros, nós transportamos vidas, isso devia ser reconhecido".

A falta de educação dos passageiros e motoristas no trânsito contribui para uma menor qualidade de vida no trabalho, pois um bom relacionamento social é um dos pontos que abordam a QVT. 


\subsection{Análise dos resultados}

Ao estipular o objetivo do estudo considerou-se que se encontraria 3 variáveis que mais afetam a QVT dos motoristas de onibus urbano da cidade do Rio de Janeiro. Mas após a apuração dos resultados, encontrou-se mais variáveis do que foi imaginado.

A Higiene Ocupacional é o conceito mais ligado à QVT, por tratar diretamente dos problemas de saúde que foram causados pelo ofício da profissão. Neste tópico, os problemas físicos citados foram dores na coluna e perda de audição. Esses problemas referem-se aos riscos ambientais físicos presentes no ambiente de trabalho. $O$ estresse também foi um dos problemas mais citados, sendo um risco ambiental do tipo ergonômico, pois afeta a saúde mental do trabalhador. O Gráfico Abaixo mostra os problemas de saúde causados pelo exercício da profissão de motoristas mais citados entre os entrevistados:

Gráfico 4

\section{Problemas de Saúde}

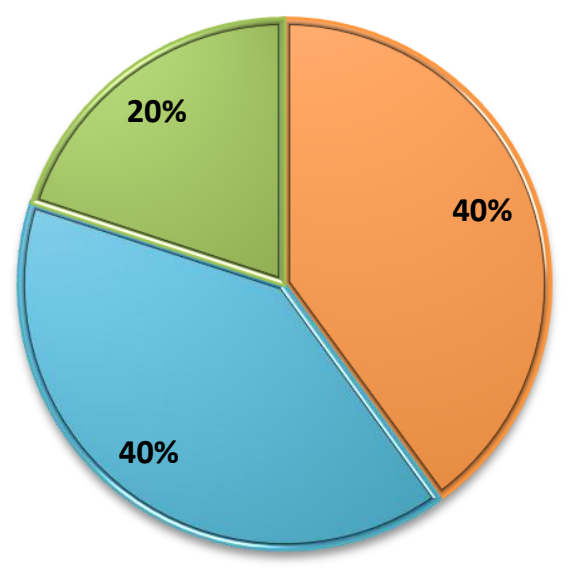

¿ Coluna

口 Estresse

प्a Audição

Apesar de não ter sido citado pelos entrevistados, o risco químico também está presente na vida dos motoristas, pois eles estão em contato com gases (CO2) e poeiras diariamente.

Ainda sobre a Higiene Ocupacional, é bom destacar que o tempo de profissão está relacionado com o aparecimento de problemas de saúde. Dos entrevistados que disseram sofrer com este problema, $80 \%$ tinham mais de 5 anos de profissão.

A insegurança no ambiente de trabalho foi um dos fatores que mais influenciam no aumento de problemas de saúde relacionados ao estresse. A grande maioria dos entrevistados, $84 \%$, não se sente seguro no ambiente de trabalho, e $68 \%$ disseram ter passado por algum tipo de risco à vida. Entre os que já sofreram com a violência, os 
problemas citados foram: Assaltados; Agressão de passageiros; Colisão com outros automóveis. O gráfico abaixo mostra o percentual dos problemas mais citados em relação a segurança:

Gráfico 5

\section{Problemas de Insegurança Sofridos}

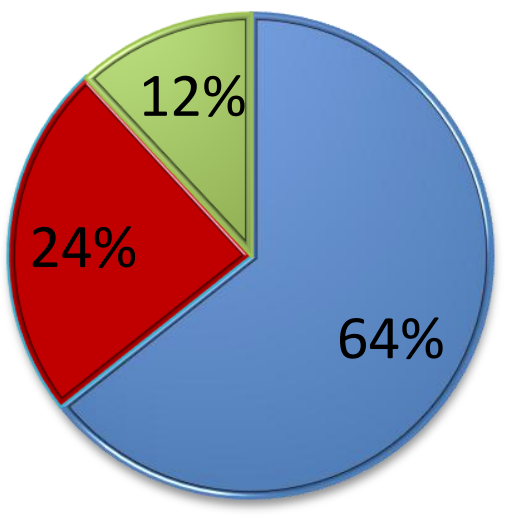

Assalto

Agressão passageiros

Colisão com automóveis

Um ponto importante a se destacar sobre a insegurança é a região por onde o ônibus trafega. Muitos entrevistados relataram passar por dificuldades em certas comunidades do Rio de Janeiro, como as regiões da Cidade de Deus e Moro do Borel. Eles disseram que assaltos e tiroteios são costantes.

Perguntados se a empresa oferece algum tipo de suporte médico que tenha como objetivo reduzir os problemas de saúde sofridos por esses profissionais no ambiente de trabalho, pode-se analisar que as empresas não dão um suporte adequado aos motoristas. As respostas sobre essa pergunta pode ser visto no gráfico a seguir: 


\section{Gráfico 6}

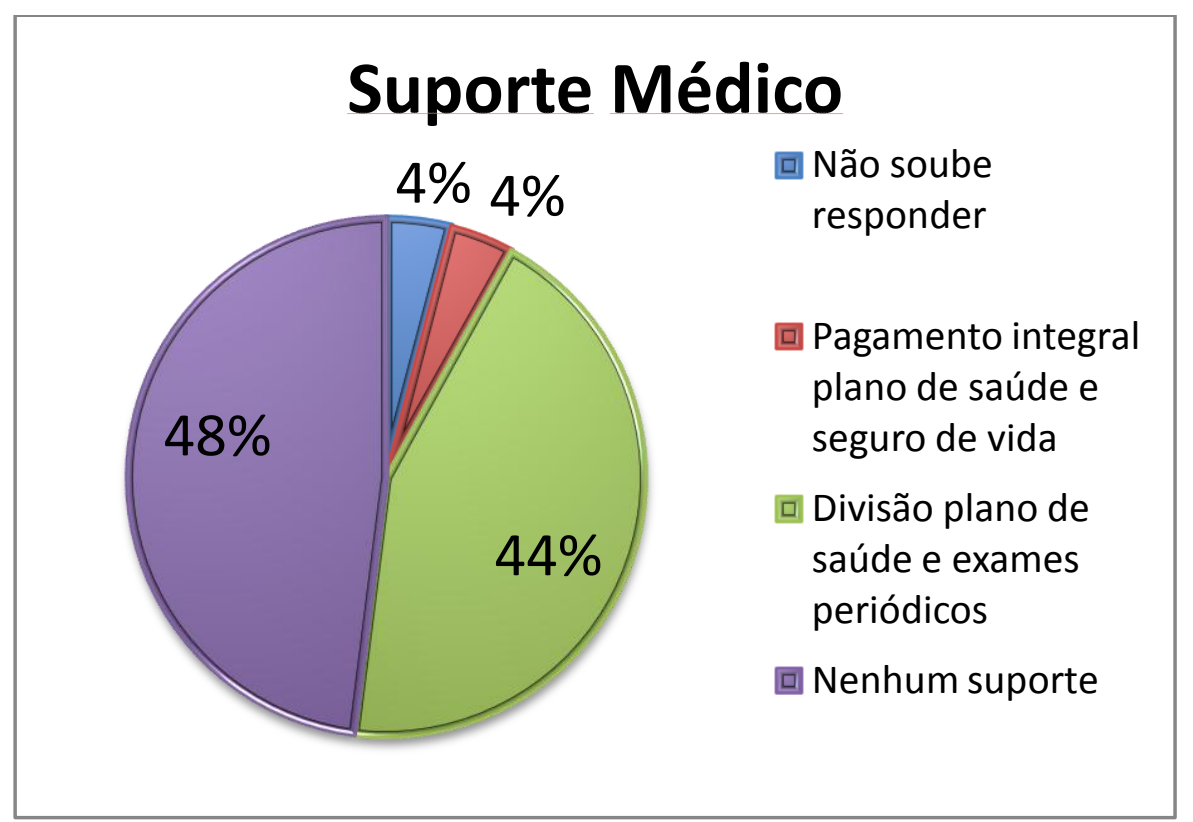

As empresas de ônibus têm papel fundamental para melhorar a QVT dos motoristas. Apesar disso, muitas não se preocupam em tomar as medidas nescessárias para melhorar essas condições. Algumas não chegam a pagar corretamente alguns direitos trabalhistas.

Perguntados se consideram que seus direitos trabalhistas são respeitados pela empresa, $64 \%$ dos respondentes disseram não considerar. Entre os direitos trabalhistas que eles consideram que não são respeitados, os mais citados foram: Baixo valor do vale alimentação; Não pagamento de horas extras, que muitas vezes são trocados por folgas extras, sem que eles escolham o que desejam; Não pagam o FGTS. Só que o problema que foi mais citado entre os entrevistados foi o problema da dupla função.

Os resultados da pesquisa de campo mostraram que $96 \%$ dos entrevistados realizam a função de motorista e cobrador, e foi um dos motivos de mais críticas em relação ao estresse no trabalho. A grande maioria dos entrevistados, $88 \%$, se dizem sobrecarregados por conta da dupla função.

A realização da dupla função, além de aumentar o nível de estresse dos motoristas, não gera um acréscimo do salário. Outra reclamação em relação a dupla função é que os motoristas de ônibus estavam acostumados a ter um outro funcionário no ônibus (cobrador) para dividir responsabilidades, caso ocorre-se algum problema. Além disso, os motoristas tinham um intervalo de tempo, quando muitos passageiros estavam entrando no ônibus, para ir ao banheiro, comprar algo para comer ou somente levantar um pouco para descansar. Com a dupla função, o motoristas não tem mais esse tempo, tendo que dar o troco aos passageiros. 
O descontentamento com a dupla função se mostrou novamente na pergunta 8, quando $44 \%$ de todos os entrevistados responderam "a volta dos cobradores", como sendo a solução mais citada para reduzir o estresse no trabalho.

O tema desgaste físico e mental analisou fatores referentes à jornada de trabalho e problemas diários em decorrência do trabalho. Neste tópico os conceitos da QVT estão muito presentes, pois esses problemas prejudicam muito o bem-estar do trabalhador.

A jornada de trabalho de um motorista pode chegar a 12 horas por dia, dando um total de 5 horas extras. $\mathrm{E}$ como foi dito anteriormente, tem empresas que não pagam horas extras, gerando bastante insatisfação nos motoristas. Mas a média dos entrevistados foi de 9 horas de trabalho por dia, dando um total de 2 horas extras.

Sobre a pergunta 3 , vide roteiro em anexo, os problemas enfrentados no dia a dia de trabalho mais citados foram: Passageiros, como passageiros que entram estressados no ônibus e discutem com os motoristas, e também passageiros que querem entrar no ônibus sem pagar; Trânsito intenso, que estão relacionados as longas jornadas de trabalho; Motoristas imprudentes, que muitas vezes fecham os ônibus causando risco de colisão. $O$ gráfico abaixo mostra os problemas sofridos no dia a dia mais citados:

Gráfico 7

\section{Problemas no dia a dia de trabalho}

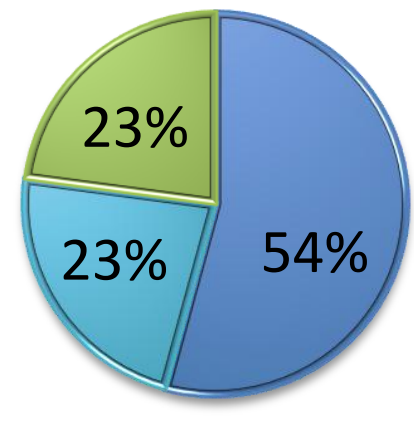

Passageiros

Transito intenso

Motoristas imprudentes

Tirando o transito intenso, todas essas variáveis mencionadas se originam da falta de educação da sociedade como um todo. Essa reclamação, da falta de educação das pessoas, foi uma das mais mencionadas na pergunta 8 , como forma de tornar sua rotina de trabalho menos estressante. Esses respondentes relataram que as pessoas devem refletir sobre a responsabilidade que os motoristas tem por lidar com vidas dentro do ônibus. Dessa forma reduziria as fechadas de motoristas e agressões de passageiros. 
Com as análises feitas, foi possível identificar as seguintes variáveis que mais afetam a QVT dos motoristas de ônibus urbano da Cidade do Rio de Janeiro: Problemas de saúde (estresse, coluna e audição); Insegurança; Se sentir sobrecarregado pela dupla função; Longas jornadas de trabalho; Sociedade mal educada. 


\section{Conclusão}

O presente estudo mostrou a precária condição de trabalho em que vivem os motoristas de ônibus. Sem dúvida, o estresse decorrente dos engarrafamentos, acidentes, prazos apertados, insegurança, falta de suporte médico, exposição ao barulho e à poluição, passageiros muitas vezes mal educados e nervosos faz com que sua qualidade de vida fique prejudicada.

Como foi dito anteriormente, o estudo teve como objetivo identificar três principais fatores que afetam a QVT dos motoristas, mas no decorrer da pesquisa foram encontrados mais fatores que o esperado. Podemos destacar como principais fatores: Problemas de saúde (estresse, perda de audição e coluna); Insegurança; Desgaste físico (dupla função e longas jornadas de trabalho); Sociedade mal educada (passageiros e motoristas). A dupla função de motorista e cobrador, foi considerada como a pior variável.

Nos últimos anos, com o aumento da utilização do RioCard nos ônibus, a profissão de cobrador tem sido extinta. De acordo com a Rio Ônibus, a função não é mais necessária dentro de 7,7 em cada 10 coletivos que rodam na cidade. Isso ocorre porque, ainda segundo a Rio Ônibus, as linhas que têm $70 \%$ ou mais passagens pagas através do bilhete eletrônico, não necessitam de cobradores dentro dos ônibus. Apesar disso,a grande maioria dos motoristas reclama de ter que dar troco a passageiros.

$\mathrm{O}$ fato de muitos motoristas estarem acostumados a trabalhar com os cobradores aumenta o descontentamento, pois, para estes, é uma função nova que eles têm que exercer e que não é paga pela empresa. O fato de ter mais um funcionário dentro do ônibus, além de diminuir a carga de trabalho dos motoristas, poderia ajudar em situações complicadas, como: passageiros estressados e assaltos. Então, seria recomendável a volta dos cobradores pelas empresas de ônibus, ou que somente sejam aceitas as passagens eletrônicas.

Outro problema relacionado com o desgaste físico são as longas jornadas de trabalho. Deve existir um limite do número de horas extras que um motorista pode fazer em um dia. Passar 12 horas por dia trabalhando é uma prática desumana, por isso, as empresas devem fazer um planejamento para reduzir as horas extras, levando em conta o tempo no trânsito que a linha costuma levar e remanejando seus motoristas. Além disso,deve ser realizado o pagamento das horas extras feitas pelos motoristas, que é uma obrigação das empresas. 
Como forma de reduzir os problemas de saúde relacionados à profissão, seria recomendável um suporte maior das empresas, como o fornecimento de um plano de saúde ao funcionário e/ou suporte médico para tratar os principais problemas encontrados (estresse e problemas na coluna).

Os problemas relacionados à sociedade mal educada e à insegurança, são responsabilidades do governo do Rio de Janeiro. A falta de segurança é um problema que todos os cidadãos cariocas passam. Então, para resolver os problemas de assaltos a motoristas, o estado deverá melhorar a segurança publica na cidade. As empresas poderiam utilizar de filmagens dentro do ônibus para identificar criminosos.

Para que a sociedade seja mais educada com os motoristas de ônibus, uma campanha de conscientização feita pelo governo ajudaria a diminuir tanto o problema de passageiros mal educados, quanto de motoristas imprudentes. A relação passageiro e motorista deve ter um foco principal, pois foi a mais citada na pesquisa, como um problema que os afeta. A fala de um dos entrevistados mostra como os motoristas se sentem em relação aos passageiros: "motorista de ônibus não é bem visto pelas pessoas e nós somos tratados como ninguém, como um lixo".

Apesar da média salarial dos motoristas de ônibus não ser baixa, não é correto deixar os motoristas nessas condições. Então, a sociedade, o governo e as empresas devem ter um olhar mais atento aos problemas que a classe passa e tratá-los de maneira mais digna.

\subsection{Sugestões e recomendações para novos estudos}

Para poder aprofundar sobre o tema e analisar esses problemas relacionados à QVT dos motoristas de ônibus da cidade do Rio de janeiro, novos estudos, com diferentes pontos de vista, devem ser feitos.

Um estudo importante é compreender quais medidas as empresas de ônibus tomam para melhorar a QVT dos motoristas, e porque certas medidas não são tomadas. E para entender melhor sobre esses questionamentos, realizar uma pesquisa qualitativa com os gestores das empresas.

Outro estudo válido é o aprofundamento da percepção que os passageiros cariocas têm em relação aos motoristas. Será importante para compreender o porquê de tanta reclamação dos motoristas em relação aos passageiros.

Outro ponto importante é a realização de uma pesquisa que analise motoristas que trafegam pelo Centro do Rio de Janeiro, já que não foi abordado neste trabalho. 


\section{Referências Bibliográficas}

BALBINO, ALINE. Estresse e Síndrome do Pânico afastam $30 \%$ dos rodoviários do trabalho. Jornal Daki, Rio de Janeiro, 13 de Maio de 2016. Disponível em: http://www.jornaldaki.com.br/\#!Estresse-e-S\%C3\%ADndrome-do-P\%C3\%A2nico-afastam30-dos-rodovi\%C3\%A1rios-do-trabalho/c11tm/5735d0ca0cf2d5f002c08613

BAZANI, Adamo. Empresas de ônibus do Rio de Janeiro desrespeitam legislação trabalhista e recebem multas de $\mathbf{R} \mathbf{\$} \mathbf{1 0 0}$ milhões. Diário do Transporte,11 de maio de 2016. Disponível em: https://diariodotransporte.com.br/2016/05/11/empresas-de-onibus-dorio-de-janeiro-desrespeitam-legislacao-trabalhista-e-recebem-multas-de-r-100-milhoes/

CHIAVENATO, Idalberto. Gestão de pessoas. Rio de janeiro: Elsevier, 2004.

FERREIRA, M. DANIELLE. Qualidade de vida no trabalho: um debate necessário. Janeiro de 2007. Trabalho de Conclusão de Curso (Pós Graduação em Gestao de Recursos Humanos) - Universidade Candido Mendes.

FRANÇA, A. C. Limongi, CRISTINA, A.Qualidade de vida no trabalho - QVT: conceitos e práticas nas empresas as sociedade pós-industrial. 2. ed. São Paulo: Editora Atlas, 2003.

FRANÇA, A. C. Limongi. Qualidade de vida no trabalho: conceitos, abordagens, inovações e desafios nas empresas brasileiras. Revista de medicina psicossomática. Vol.01, n 2. Abr /Mai /Jun 1997 Rio de Janeiro.

GAYOSO, Lucas. Com aumento do uso do RioCard, cobrador vira profissão em extinção. O dia Rio, 9 de abril de 2016, 00:03. Disponível em: http://odia.ig.com.br/rio-dejaneiro/2016-04-09/com-aumento-do-uso-do-riocard-cobrador-vira-profissao-emextincao.html 
GONÇALVES, A.; GUTIERREZ G. L,; VILARTA R. (Organizadores). Gestão da Qualidade de Vida na Empresa. Campinas, SP: IPES Editorial, 2005.

GUEIROS, M. PEDRO. Condutores de alta tensão: a rotina estressante dos motoristas de ônibus do Rio. Jornal O Globo, Rio de Janeiro, 19 de Julho de 2015, 6:00. Disponível em: $\quad$ http://oglobo.globo.com/rio/condutores-de-alta-tensao-rotina-estressante-dosmotoristas-de-onibus-do-rio-16836705

OLIVEIRA, P. M.; LIMONGI-FRANÇA, A. C. Avaliação da gestão de programas de qualidade de vida no trabalho. Revista de Administração Eletrônica, v. 4, n. 1, 2005, p. $1-21$.

OLIVEIRA, Patricia e FRANÇA, A. C. Limongi. Avaliação da gestão dos programas de qualidade de vida no trabalho. ERA Eletrônica- FGV. Vol. 04. N 09. Janeiro/Julho 2005. São Paulo.

PEIXOTO, N. H.; FERREIRA, L. S. Higiene ocupacional I. Santa Maria : UFSM, CTISM ; Rede e-Tec Brasil, 2012.

PREVIDELLI, AMANDA. As 10 piores profissões do Brasil. Guia do estudante, 12 de Setembro de $2013 . \quad$ Disponível em: http://guiadoestudante.abril.com.br/blogs/pordentrodasprofissoes/as-10-piores-profissoesdo-brasil/

QUIRINO, T. R.; XAVIER, O. Qualidade de vida no trabalho de organização de pesquisa. Revista de Administração, São Paulo, v. 22, n. 1, p. 71-82, jan. 1987.

SOUSA, L. M. M.; MINICHELLO, M. M. Saúde ocupacional -- 1. ed. -- São Paulo : Érica, 2014.

SOUZA, J. C.; GUIMARÃES, L. A. M. Insônia e qualidade de vida. Campo Grande: UCDB, 1999.

The WHOQOL Group 1997. The World Health Organization quality of life assessment (WHOQOL): Measuring Quality of Life. WHO/MSA/MNH/PSF/97. 
WILHEIM, J. DEÁK, K. Maximização da qualidade de vida em conjuntos habitacionais. São Paulo: Cohab, 1970. 


\section{Apêndices}

\section{Apêndice A: Roteiro das entrevistas}

\section{PONTIFÍCIA UNIVERSIDADE CATÓLICA DO RIO DE JANEIRO - PUC-RIO - DEPARTAMENTO DE ADMINISTRAÇÃO 2016}

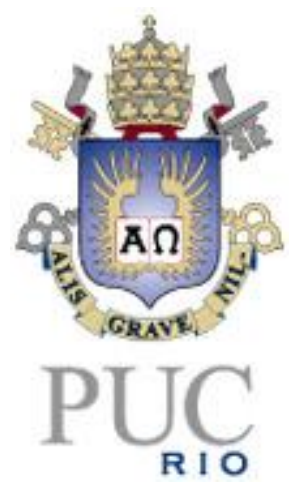

Essa entrevista faz parte de uma pesquisa monográfica TCC, do aluno Pedro Victor Carvalho Fernandes, do curso de administração de empresas. O objetivo dessa pesquisa é identificar os principais fatores que afetam a qualidade de vida no trabalho de motoristas de ônibus na cidade do Rio de Janeiro.

\section{Roteiro}

Região de trabalho:

Tempo na profissão de motorista de ônibus:
Idade:

Turno em que trabalha:

1) Você desempenha outra função na empresa de ônibus, além de motorista? Se sim, Qual(ais)? E você se sente sobrecarregado por conta disso?

2) Quantas horas, em média, você passa no seu trabalho de motorista?

3) Você enfrenta problemas no seu dia-a-dia de trabalho sendo motorista de ônibus? Se sim, quais você considera os piores? Cite pelo menos 3. E qual é o que mais te afeta?

4) Que tipo de risco você já passou no seu trabalho? Você se sente seguro no seu ambiente de trabalho? 
5) Você tem ou teve algum problema de saúde causado por seu trabalho de motorista? Se sim, cite quais. Se não, ao que você deve este fato?

6) Você considera que seus direitos trabalhistas são respeitados pela empresa?

7) A empresa oferece algum tipo de suporte médico, que tenha como objetivo diminuir problemas sofridos por você no seu ambiente de trabalho?

8) O que você acha que poderia ser melhorado para tornar a sua rotina de trabalho menos estressante? 


\section{Apêndice B: Sínteses das entrevistas}

\section{Entrevista 1}

Este entrevistado, apesar de pouco tempo na profissão (apenas 8 meses), apresentou bastante informações e deu respostas longas. Quando perguntado se ele se sente sobrecarregado por ter a dupla função de motorista e cobrador, ele não titubeou em responder que sim: "é muito estressante, tem os passageiros para você orientar, cobrar e ainda ter que dirigir ". A resposta referente a pergunta 2 foi de 8 a 9 horas por dia.Sobre a pergunta 3, o entrevistado mostrou que tinha bastantes problemas para falar e destacou que os piores problemas que ele passa diariamente é a falta de educação no transito, como nesse trecho relatado: "tem pessoas de carros pequenos que entram na frente e freiam; Os mototaxis, são muito inocentes, não respeitam os ônibus, entram sempre no lado cego do motorista...O próprio motorista de ônibus não respeita,não tem um respeito um pelo outro, não respeita o passageiro". Perguntado sobre o pior problema dentre os citados, ele disse que os motoboys são os piores, por entrarem na frente e no ponto cego do motorista, causando risco de acidente. Outro ponto importante relatado pelo entrevistado é a falta de segurança, por conta da região que ele trafega, "Eu estava fazendo uma linha da empresa e entrei em um morro, não conhecia. Entrei em um morro lá e o pessoal apontou arma. Não me sinto seguro. Como na minha linha atravessa a cidade de Deus, é risco ai né? Tem tiroteio, pessoal assalta ônibus. ". Sobre a pergunta 5 , ele diz que não sofreu com problemas de saúde relacionado ao trabalho, mas que tenta se precaver: "Eu durmo bem, como bem, procuro me relaxar mais, pra não me estressar tanto com passageiro, nem motorista ". Já sobre a pergunta 6 , ele se confunde um pouco para citar quais direitos trabalhistas não são respeitados pela empresa, mas cita que a empresa não está pagando o fundo de garantia, a empresa não paga pela dupla função e o ticket alimentação está muito baixo. A pergunta 7 ele não soube responder direito, pois disse que não procurou saber sobre isso. Dentre os pontos que ele considera que poderiam ser melhorados, para tornar sua rotina de trabalho menos estressante, destacam-se o pagamento de plano de saúde e a segurança dentro do ônibus: "ter um segurança dentro do ônibus, porque encontramos muito dificuldade quando passamos pela cidade de Deus ". O entrevistado deu muito ênfase de que a região da cidade de Deus é bastante complicada em relação a segurança.

\section{Entrevista 2}

O entrevistado é o único que não realiza a dupla função, porque na sua empresa só aceita cartão RioCard, pois é uma linha especial para o aeroporto.Por conta disso, não se sente sobrecarregado, dizendo ser uma linha: "tranquila". Ele diz fazer uma media de 9 a 10 horas de trabalho por dia, dependendo do transito. Este entrevistado não apresentou muitas reclamações, parecia estar satisfeito com a empresa em que trabalha, pois quando foi 
perguntado se seus direitos são respeitados pela empresa, ele disse: "Sim, acredito que sim. Essa aqui sim. Eles pagam hora extra, quando passamos do horário normal de trabalho.... Eles oferecem plano dentário, seguro de vida. ". A pergunta 8 foi a que ele se mostrou mais disposto a falar, dando uma resposta com mais argumentos e mostrando uma maior insatisfação. Ele destacou que poderia ser melhorado o respeito no transito, pois eles lidam com vidas: "Os motoristas de carros pequenos são muito abusados em relação aos carros grandes. Os motoristas de ônibus trabalham com carros grandes, transportam vidas, e os carros pequenos se jogam na sua frente, e a gente sempre tem que estar evitando acidentes. "Sobre as perguntas 3,4 e 5 ele deu respostas curtas, dizendo não ter problemas.

\section{Entrevista 3}

Pode ser observado que o entrevistado estava com vontade de responder a entrevista.Além de se sentir sobrecarregado, por ter que dirigir e cobrar, ele reclama bastante de não receber pela dupla função: "Dupla função, a gente faz duas funções e recebe por uma. Se você for somar direito, não ganhamos por isso. “. Ele passa uma média de 8 a 10 horas no trabalho.Sobre a pergunta 3 , ele parece não conseguir definir 3 problemas, pois diz ter muitos, mas cita passageiros e motoristas estressados e destaca como principal problema a insegurança: “Já fui assaltado, já tive arma na minha cabeça, já fui refém... dentro do ônibus até tem as câmeras, mas elas não inibem esses tipos de crimes, só se você (motorista) estiver roubando (da empresa)". A questão da falta de segurança se mostrou um fator de bastante insatisfação por parte do motorista. Ele relata também que já teve problemas de saúde causada pelo desgaste da profissão: "já tive problema de coluna. Já estive afastado por isso. ". Apesar disso, ele diz que a empresa não oferece um suporte medico, apenas oferecem planos de saúde que são debitados do salário dos motoristas.Sobre a pergunta 6 , ele diz que seus direitos não são respeitados, e cita que eles não recebem pela dupla função, mas parece ter dificuldades de saber ao certo quais direitos não são respeitados: "A gente sempre sai perdendo, o que a gente deveria receber de verdade a gente nunca recebe ". Ao ser perguntado sobre o que poderia ser melhorado para tornar sua rotina menos estressante, ele considera uma melhoria não só pros motoristas, mas para a sociedade como um todo: "A educação tem que vir dos passageiros, motorista, do governo, da sociedade como um todo.".

\section{Entrevista 4}

Foi observado que o entrevistado, apesar de querer responder a entrevista, estava com um pouco de pressa. Em algumas respostas ele não se alongou muito. Sobre a pergunta 1, ele diz se sentir sobrecarregado pela dupla função. Ele tem uma média de 8 a 9 horas de trabalho. Entre os problemas que ele enfrenta diariamente, ele cita estresse com passageiros, transito e considera o pior a prestação de contas: "no final do serviço, quando 
eu paro o ônibus, eu tenho que fechar o caixa e ir lá na recebedoria e pagar o valor arrecadado do ônibus. “. Ele responde na pergunta 4 sobre a falta de segurança no trabalho e os problemas de falta de segurança que ele já passou sendo motorista: "ameaça de morte e ameaça de bater. Sempre tem alguma coisa. Não me sinto seguro. ". Sobre a pergunta 5, ele diz não ter tipo problemas de saúde e não se cuida.Em relação a empresa, ele diz não receber pela dupla função e o plano de saúde não é pago integralmente pela empresa. Ao ser perguntado sobre o que poderia ser melhorado, ele diz que é a volta dos cobradores.

\section{Entrevista 5}

O entrevistado tem bastante tempo na profissão de motorista de ônibus (25 anos), permitindo uma análise melhor sobre os problemas sofridos pela classe ao longo do tempo. Ele se diz sobrecarregado por conta de ter que dirigir e cobrar. Ele passa 11 horas, em média, no trabalho de motorista. Uma média alta se comparada a todos os entrevistados. Dentre os problemas sofridos na sua rotina de trabalho, ele destaca a falta de educação no transito e principalmente passageiros mal-educados: "São coisas que as vezes acontece, mas não é sempre.Como passageiro estressado, de querer exigir algumas coisas que não está ao nosso alcance. ". Apesar de nunca ter sofrido nenhum risco a sua vida no seu ambiente de trabalho, ele não se sente seguro. Ele já sofreu problemas de saúde por conta de sua profissão: "Sim, perda de audição, 10\%... A pressão por causa de estresse. Você não quer se estressar, mas sempre tem algo que causa estresse. Eu tenho um estresse que eu já fui até ao médico devido a isso". Em relação a perda de audição, ele diz que os motores são muito barulhentos, apesar dos antigos motores fazerem mais barulho do que os atuais, continuam sendo muito alto. Em relação a perguntas 6 , ele responde que a empresa paga as horas extras trabalhadas e paga um valor pequeno por conta da dupla função. Já a pergunta 7, ele respondeu: "Não. Nem plano de saúde, nada ". A melhoria desejada por ele é o fornecimento de plano de saúde pela empresa, devido aos diversos problemas que eles sofrem diariamente. Ele pareceu se incomodar bastante com os problemas de saúde que ele sofre por conta da profissão, a perda de audição e o estresse.

\section{Entrevista 6}

O entrevistado tem pouco tempo de profissão, 10 meses, podendo ainda não ter sofridos com todos os problemas que só com bastante tempo de profissão ocorrem. Durante a entrevista o fiscal chamou ele para pegar o ônibus, mesmo assim ele pediu para o fiscal aguardar pois queria terminar a entrevista. Perguntado se sente sobrecarregado por conta da dupla função, de motorista e cobrador ele diz que sim e fez uma brincadeira que faz função de segurança, quando passageiros querem entrar sem pagar.Ele faz uma média de 9 horas de trabalho por dia. Dentre os problemas enfrentados no dia-a-dia de trabalho, ele cita as pessoas que não querem pagar a passagem: "Pessoas que não querem pagar a passagem, entrando pela porta de traz do ônibus ou pulando a catraca", e também cita 
problemas com troco e com transito intenso. Mas ele considera o pior problema o estresse diário. Inclusive ele relata já ter sofrido problemas de saúde causado pelo estresse: "pressão alta, alterou a pressão relacionado ao estresse ". Ele cita o problema de passageiros querem entrar sem pagar em duas perguntas, demonstrando uma insatisfação grande em relação a isso. Sobre a pergunta 4, ele respondeu: "Assalto. Não. ".Sobre a pergunta 6, ele diz: " Não, falta muita coisa ainda ". E cita como exemplo, as empresas não pagarem pela dupla função. Sobre a pergunta 7, ele diz: "Não, não tem plano de saúde, não tem nada disso ". Ele propõe que tenham mais ônibus nas ruas, pois costumam ir lotados e isso contribui para o aumento de estresse. Como pode ser visto no trecho destacado: "Colocar mais ônibus nas linhas para poder diminuir o excesso de passageiros, porque o ônibus fica muito lotado e isso também gera estresse. ".

\section{Entrevista 7}

O entrevistado se mostrou bastante sobrecarregado pelo excesso de funções que ele exerce no dia-a-dia, além de motorista e cobrador, ele também tem que fazer papel de segurança: "Sim, é muita carga.Além de dirigir, tendo que ter a atenção no transito aqui no Rio de Janeiro, passar troco, abrir porta traseira do ônibus porque tem alguém querendo invadir. ". Ele passa em média 8 a 9 horas no trabalho. Dentre os problemas que ele passa diariamente, ele destaca: "Passageiro, as vezes faz questão de 5 centavos, não tem troco porque a empresa não dá; A sirene as vezes não toca com qualidade, você não ouve; Alguns ônibus tem assentos com um fundo no meio. O pior problema é dirigir e cobrar. ". Apesar de já ter sido assaltado, ele diz que não tem medo de dirigir um ônibus pelas vias do Rio. Ele relata o perigo de uma região por onde ele trafega na zona oeste: "Seguro não é, porque já foram muita gente assaltada, inclusive eu no morro do Borel ". Sobre a pergunta 5 , ele diz que não, e que: " A empresa tem médico, tem exames ". Mas sobre a pergunta 7, o entrevistado diz que a empresa oferece um suporte medico básico e o plano de saúde é descontado do salário. Ele reclama que além da empresa não pagar hora extra, ela não aceita fazer acordo com funcionários que desejam sair da empresa. Para o entrevistado, a volta dos cobradores melhoraria bastante o dia-a-dia de trabalho. Ele cita também a falta de tempo que ele tem parar fazer coisas básicas, como ir ao banheiro. Conforme ele relata: "Você tendo um cobrador, enquanto os passageiros vão passando, o motorista pode ir ao banheiro. As vezes não dá tempo de fazer um lanche, não dá tempo de almoçar “.

\section{Entrevista 8}

O entrevistado tem um vasto tempo na profissão de motorista, com 13 anos de profissão, e deu uma entrevista bastante construtiva, com muitas informações. Ele não se sente sobrecarregado pela dupla função de motorista e cobrador, ele diz ser: "Normal". Com média de 10 a 12 horas de trabalho por dia, ele cita que o principal problema enfrentado no seu dia-a-dia é a falta de educação das pessoas: "O grande problema é que ninguém 
respeita ninguém. Ninguém tem educação com ninguém...se todo mundo fizer certo, respeitar as pessoas em seu trabalho, eu acho que o andamento do transporte e da educação iam melhorar muito. ". Mesmo com muito tempo de profissão, ele nunca foi assaltado, e apesar de não se sentir seguro no ambiente de trabalho, ele diz que em relação ao assalto, pode ocorrer em qualquer lugar, não só dentro do ônibus Ele relata não ter tido problema de saúde por conta da profissão, mas isso se deve muito pela preocupação que ele tem com sua saúde, conforme ele fala: "Quando eu cheguei aos 45 anos, eu procurei me policiar. Me doutrinando na alimentação, na carga horária para dormir, o exercício físico como caminhada ". Ele se mostrou bastante contente com o tratamento que a empresa tem com os funcionários, tanto nas questões trabalhistas: "a empresa nunca me deixou a desejar em nada.Recebemos por dupla função. " ; quanto nas questões da saúde dos funcionários: "Não tenho o que reclamar da empresa. Quando você vai entrar, ela faz um check-up geral dentro da empresa, e quando você sai você também recebe outro check-up. Inclusive, nós temos um serviço lá dentro da empresa de seguro de trabalho. ". Ele propõe que se coloque uma música ambiente nos ônibus, com o objetivo de acalmar as pessoas e deixar o ambiente menos estressante. Enquanto estava fazendo a entrevista, ocorreu uma discussão entre uma passageira com um motorista de ônibus, e o entrevistado enfatiza que nem sempre a culpa é dos motoristas: "se o motorista da uma freada mais brusca, não é porque ele quis, mas por uma necessidade. Ai o passageiro chama logo a atenção dele: "maluco!", "Irresponsável!", "Se eu caio, eu te processo!" ".

\section{Entrevista 9}

Pode ser observado que o entrevistado estava com um pouco de pressa para a realização da entrevista, pois seu ônibus estava prestes a sair. Ele diz que se sente sobrecarregado pelo excesso de funções, que além de motorista e cobrador, ainda tem que fazer papel de segurança. Ele tem uma média de 8 a 9 horas de trabalho por dia. Dentre os que ele enfrenta diariamente, ele destaca os motoristas irresponsáveis e passageiros estressados. Mas o principal problema é: "O que mais me afeta é o transito, dirigir e cobrar. ". Sobre a pergunta 4, ele diz que nunca passou por nenhum risco e se sente seguro. Ele diz que não apresentou problemas de saúde porque ainda tem pouco tempo de profissão, mas que colegas com mais tempo de profissão, tem problemas. Sobre as perguntas 6 e 7 , ele respondeu que: "não sabe" . Para melhorar o dia-a-dia de trabalho de motoristas de ônibus, ele propõe: "O prefeito, ou governador, deviam mudar esses ônibus, colocar só cartão. Ai daria para dirigir e cobrar, sem cobrador. ".

\section{Entrevista 10}

O motorista tem pouco tempo de profissão, apenas 4 meses, e por conta disso pode ter um olhar mais superficial sobre o desgaste da profissão. Ele não se sente sobrecarregado pela dupla função, e faz uma média de 8 horas por dia no trabalho.Apesar 
de dizer não se sentir sobrecarregado por conta da dupla função, os principais problemas que ele diz passar no seu dia-a-dia de trabalho, muitos estão relacionados com a função de cobrador: "Às vezes os passageiros vêm com 50 reais, a empresa não dá troco... Além do tempo na demora de dar o troco, aí os outros passageiros já começam a reclamar. Aquele estresse do dia-a-dia ". Sobre a pergunta4, ele diz nunca ter sofrido com risco de vida e que se sente seguro, mas que: "A gente ta sujeito a tudo né? " Ele considera seus direitos trabalhistas respeitados e que a empresa oferece suporte medico para enfrentar os problemas corriqueiros, como estar passando mal. Em relação a pergunta 5, ele diz não ter sofrido com esse tipo de problema, mas devido ao seu pouco tempo de profissão, está resposta já era esperada. Ao ser perguntado sobre o que poderia ser melhorado para deixar sua rotina menos estressante, ele diz: "Se fosse bilhete único direto, para não ter contato com o dinheiro e não ter risco. Porque a gente lida com dinheiro ali, as vezes a gente está com duzentos e pouco, é uma linha que dá dinheiro. ". Apesar de ter relatado que se sente seguro no ambiente de trabalho, a pergunta 8 mostra que ele tem uma preocupação com excesso de dinheiro que anda no ônibus, podendo causar assaltos.

\section{Entrevista 11}

O entrevistado pareceu estar bastante insatisfeito com as condições de trabalho que ele vive, inclusive mencionou que gostaria que o trabalho ajudasse a melhorar a condição da classe de motoristas de ônibus. Com 10 anos de profissão, ele diz que a dupla função, de motorista e cobrador, o deixa muito sobrecarregado. Ele passa de 7 a 12 horas no seu ambiente de trabalho, e diz que a empresa está trocando as horas extras, por folga. Dentre os problemas enfrentados no dia-a-dia, ele cita o problema de dar troco aos passageiros; Estresse gerado por passageiros irritados; E o que ele considera o pior problema que é o Estresse do transito. Perguntado se ele já passou por um risco no ambiente de trabalho, ele diz que enfrenta riscos com fechadas de outros veículos e com policiais: "O pior problema é o policia, te fechar e colocar a pistola na sua cara, sem dúvida, que é tentar contra o direito da pessoa. ". Ele diz que não se sente seguro no ambiente de trabalho. Ele relata que está começando a ter problemas de saúde causados pelo estresse no ambiente de trabalho. Em relação a empresa, ele se mostra bastante descontente e relata um caso que aconteceu com um colega de trabalho: "foi mandado embora, porque faltou a um dia de trabalho. Queriam que ele assinasse uma justa causa, e ele não assinou. Pagaram só os dias trabalhados por ele e mandaram ele procurar a justiça... dupla função também não pagam, tem que colocar na justiça. ". Outro ponto abordado por ele é o baixo valor do vale alimentação de 195 reais por mês. A empresa não oferece planos de saúde, apenas se o funcionário pagar por conta própria: "Tem um plano de saúde que é oferecido pela empresa, mas você tem que pagar, não é direito. Eu canso de brigar com meus amigos para reivindicar isso, um plano de saúde, para você para sua família. Porque isso aí acaba com a 
pessoa. ". Para ele, a principal sugestão para tornar o trabalho menos estressante é a volta dos cobradores. Mas ele também acha que poderia ter um plano de saúde para os motoristas e o vale alimentação com um valor maior. Esse foi o entrevistado que se mostrou mais indignado com a sua qualidade de vida no trabalho.

\section{Entrevista 12}

O motorista tem pouco tempo de profissão, apenas 7 meses, mas apesar disso ele considera "sinistro" e "muito cansativo" ter que desempenhar duas funções, motorista e cobrador. O entrevistado deu respostas curtas, parecia não querer responder as perguntas de forma completa e verdadeira. Ele passa uma média de 8 a 9 horas no trabalho. Sobre a pergunta 3, ele primeiramente não compreendeu e depois de explicar melhor a pergunta, ele disse que não tem nenhum problema. Ele se sente seguro no ambiente de trabalho, considera seus direitos trabalhistas respeitados pela empresa, mas disse que a empresa não oferece suporte medico aos funcionários. Para ele, uma forma de tornar a rotina menos estressante e com a volta dos cobradores. Sobre a pergunta 5, ele disse: "Não, até agora não" . A entrevista não foi de grande ajuda, em termos de conteúdo.

\section{Entrevista 13}

Apesar de o entrevistado ter bastante tempo na profissão de motorista de ônibus, mais de 40 anos, ele deu respostas curtas e mais objetivas.Primeiramente ele relata que sente sobrecarregado pela dupla função que exerce, de motorista e cobrador. Sua carga horária diária é de mais ou menos 9 horas. Ele cita, como problemas que ele passa diariamente: passageiros estressados;Falta de tempo para ir ao banheiro; Problemas no ar condicionado no ônibus, principalmente na época do verão onde o calor é mais intenso. Ele se mostrou bastante incomodado com a questão da segurança no trabalho, inclusive relatou que na semana passada (em comparação com o dia em que a entrevista foi feita) ele sofreu com um assalto a mão armada dentro do ônibus: "estamos sujeitos a isso toda hora. Seguro de jeito nenhum, a gente é obrigado a ceder, o que assaltante quer, passageiro quer, a gente não sabe com quem ta lidando, tem que ceder tudo que pedem. ". O entrevistado diz que sofre com problemas de saúde que foram causados pelo seu trabalho de motorista, "estresse constantemente acontece, dor de barriga de nervoso ". Em relação a empresa, ele diz que não considera que seus direitos trabalhistas são respeitados, dizendo que existe muita cobrança e tudo que quebra dentro do ônibus,os motoristas tem que pagar. A empresa não da nenhum tipo de suporte médico aos motoristas. Quando perguntado sobre o que podia ser melhorado, ele diz: "Ter um horário fixo para começar e terminar; Material melhor; Manutenção no ônibus porque frequentemente acontece problema; Diminuir cobrança de produção. ".

\section{Entrevista 14}


Primeiramente, o entrevistado diz estar muito sobrecarregado devido a dupla função, como destaca o trecho: "Sinto muito sobrecarregado mesmo, tem que olhar retrovisor, dirigir, dar informação, saber lugar de tudo e ainda receber o dinheiro. ". Ele faz uma média de 8 a 10 horas de trabalho por dia. Dentre os problemas sofridos por ele diariamente, ele destaca como o pior problema a falta de troco para os passageiros. Em relação a segurança, ele não se sente seguro dirigindo pelas ruas do Rio de Janeiro, "eu trabalho dentro da Cidade de Deus e as vezes tem tiroteio lá. Quem conhece a linha já fica esperto, quem não conhece se joga no chão, ontem mesmo teve tiroteio por lá. ". Apesar de não ter sofrido problemas de saúde relacionado a sua profissão, ele diz que muitos amigos de profissão tem problemas relacionados a saúde, como por exemplo estresse e nervosismo. Sobre a pergunta 6 , ele diz que alguns direitos são respeitados, mas outros não como o não recebimento por dupla função. A empresa oferece suporte médico, inclusive psicológico, mas são descontados do salário do funcionário. Ele diz sobre o que podia ser melhorado: "Deveria ser um pouco mais respeitada essa atividade, uma pessoa só dirige por 80, 100 pessoas dentro do ônibus, e ninguém reconhece isso como um risco. Os passageiros não facilitam a qualidade do nosso trabalho, são mal educados. ".

\section{Entrevista 15}

Essa foi a única entrevista em que o entrevistado é uma mulher. O fato de ser a única mulher se deve por não ter encontrado motoristas do sexo feminino, mostrando ser uma minoria. Sobre a pergunta 1 , ela diz que não se sente muito sobrecarregado porque não é uma linha que possui muitos passageiros, mas as vezes tem problemas com troco para passageiros. Inclusive, sobre a pergunta 3, ela diz não ter muitos problemas, mas que o pior problema são com passageiros. Ele passa uma média de 9 horas diárias no ambiente de trabalho. Sobre o risco diário da profissão, ela diz: "Já fui agredida por um passageiro que tentou entrar pela porta de traz no ponto final ... Veio para porta da frente e ficou forçando a porta, até que abriu e ele me deu uma "mochilada". Tem esse tipo de risco, mas a gente tem que conviver ". Sobre a pergunta 6 , ele diz que a empresa não paga as horas extras trabalhadas e que não recebem pela dupla função. E sobre o que poderia ser melhorado, ela diz: "Melhorar os carros da empresa que estão velhos, voltar o cobrador para o motorista não ter que se preocupar com o trabalho dessa função. ". Sobre as perguntas 5 e 7, não foram citadas pois a entrevistada deu a seguinte resposta: "Não" .

\section{Entrevista 16}

O entrevistado deu respostas curtas e com pouco conteúdo. O entrevistado se diz sobrecarregado por conta da dupla função, dizendo ser: "complicada".Ele é um dos únicos entrevistados que não faz hora extra, tendo uma media de 7 horas de trabalho por dia.Com 27 anos de profissão, o ele diz que o pior problema que ele passa diariamente são os assaltos e passageiros estressados. Sobre a questão de assaltos, ele diz: "já passei por isso 
quatro vezes.Não, ninguém se sente seguro e eu não sou diferente de ninguém. ". Apesar de tanto tempo de profissão, ele diz nunca ter tido problemas de saúde relacionado ao seu trabalho e nem toma medidas para evitar problemas de saúde. Em relação a pergunta 8, ele diz que melhoraria de os passageiros fossem mais educados e tivesse mais segurança dentro dos ônibus. A pergunta 6, a resposta foi: "Não". E a 7 que tem suporte medico terceirizado.

\section{Entrevista 17}

O motorista, que já está a 8 anos na profissão, se sente sobrecarregado por conta da dupla função, "Muito sobrecarregado, aqui você trabalha com vidas e um deslize seu pode ser muito grave. ". Ele faz uma média de 10 horas de trabalho por dia.Ao fazer a pergunta 3 , sobre os problemas sofridos por ele diariamente, ele se mostra bastante descontente e responde: "Muito estresse... eu trabalho na cidade de Deus e os meninos pulam a roleta e eles querem que eu pague isso. Qualidade de vida muito ruim. ". Ele relata que todo dia é um risco, e é assaltado constantemente. A questão da região pesa bastante na relação com assaltos. Além dos riscos a vida, ele sofreu $5 \%$ de perda de audição por conta do barulho alto no seu ambiente de trabalho. Em relação a empresa, ele responde as perguntas 6 e 7 , respectivamente: "Não, tem 3 anos que a empresa não deposita nosso FGTS." ; "A empresa não oferece nada, te da a ferramenta e você se vira. ". Perguntado sobre o que podia ser melhorado, ele diz: "Voltar a função do cobrador, tornaria menos estressante e inibiria um pouco os assaltos por ter mais uma pessoa no ônibus. Mas as empresas só pensam em dinheiro, carros ruins, ar condicionado que não funciona direito... ". Ao fazer a entrevista, deu para notar que o motorista não está nem um pouco satisfeito com a empresa e com a sua segurança. Pareceu estar com um grau de estresse elevado.

\section{Entrevista 18}

O motorista estava no fim do seu expediente, a caminho de pegar um ônibus para ir para casa, então ele estava cansado depois de um dia longo de trabalho. Com 11 anos de profissão, o entrevistado diz se sentir um pouco sobrecarregado por conta da dupla função. Ele passa uma média de 10 a 11 horas trabalhando por dia. Ele cita como pior problema enfrentado diariamente o estresse, mas cita outros problemas também, como trânsito e passageiros que não querem pagar: "trânsito no verão fica caótico porque nas linhas que eu passo em comunidade eles não respeitam e querem pular a roleta". Nesse trecho destacado, pode se fazer uma análise que a época do ano e a região por onde ele trafega, são variáveis que influenciam o aumento de passageiros quererem entrar sem pagar. Ele não se sente seguro no ambiente de trabalho, já sofreu com assaltos. Sobre a pergunta 5, ele responde: "Problema na vista, coluna, tendinite, coisas que a maioria dos motoristas têm. Problemas da profissão mesmo ". Já sobre a pergunta 6, ele primeiramente demora um pouco para responder, fica pensativo, e responde que o FGTS nunca é depositado no dia e 
sobre a função de cobrador, ele fala: "eles pagam só 7 reais a mais pra gente por isso. Se for parar pra analisar tem muita coisa errada ". Ele também cita que nenhuma empresa de ônibus respeita os motoristas.Sobre a pergunta 7, ele diz que a empresa oferece um plano que é descontado do salário. Dentre as melhorias que poderiam ser feitas para tornar o trabalho menos estressante, destaca-se: "a carga horária, a folga podia ser maior, dois dias da semana consecutivos, podiam aumentar o salário já que agora é motorista e cobrador ".

\section{Entrevista 19}

Durante a entrevista, o fiscal chamou o motorista para pegar o ônibus, fazendo com que as respostas fossem mais rápidas. O entrevistado diz que é "sacrificante" ter que desempenhar a função de motorista e cobrador, além de ter uma média de 10 horas de trabalho por dia. Dentre os problemas que ele passa diariamente, destaca: "Estresse, fadiga, ansiedade pra acabar o serviço logo. Mas ansiedade é o pior, acabar o serviço dentro dos conformes, sem acidentes ou outros problemas. ". Sobre a pergunta 4, ele relata que um passageiro já tentou agredi-lo, e ele tenta "trabalhar da melhor forma possível" para evitar riscos. O motorista sofre de dor nas costas por conta do seu trabalho. Em relação as medidas que a empresa toma com os motoristas, ele considera que seus direitos trabalhistas são respeitados pela empresa, mas ele já passou por outras que não respeitavam. A empresa oferece um posto médico para medicamentos básicos e oferece um plano de saúde que é descontado do salário.Perguntado sobre o que pode ser melhorado, ele diz: "Ser mais respeitado por todos, principalmente passageiros, nós transportamos vidas, isso devia ser reconhecido. ".

\section{Entrevista 20}

Com 5 anos de profissão, ele se sente "muito sobrecarregado" por conta da dupla função de motorista e cobrador. Ele diz que hoje em dia melhorou, uma média de 10 horas de trabalho por dia, mas que antigamente era umas 12 horas.Ao fazer a pergunta 3 , antes mesmo de terminar a pergunta, ele responde sem pensar: "todo dia!". Ele cita problemas com transito, passageiros e de troco. Esses são os principais problemas, mas considera o problema de troco como, o pior.Em relação a pergunta 4, o entrevistado mostrou sofrer bastante com a insegurança: "Briga direto, já apanhei de passageiro, é normal. No trânsito já apontaram arma pra mim várias vezes, tacaram pedra no ônibus, sorte que não pegou em mim. Não tem como se sentir seguro, é sozinho, e ainda trabalha com dinheiro. ". Ele relata que desde que começou a trabalhar de motorista de ônibus, começou a sentir dores na coluna. Perguntado se seus direitos são respeitados pela empresa, ele se enrola um pouco na resposta, e diz: "Não, os horários por exemplo, motorista que agora é cobrador tem que prestar conta, acaba nosso expediente e ainda temos que ir na empresa e não recebemos por isso. ". A empresa não oferece nenhum suporte medico: "tudo por nossa conta ou público ". Sobre o que poderia ser melhorado para tornar o trabalho menos estressante, ele 
diz que poderiam voltar com os cobradores pois diminuiria bastante o estresse com passageiro.

\section{Entrevista 21}

Apesar de ter bastante tempo de profissão, 27 anos, ele deu respostas curtas, mas com certeza do que estava falando. O motorista faz um média de 10 a 12 horas de trabalho por dia. Sobre a pergunta 1 , ele diz que todos os motoristas, inclusive ele, se sentem sobrecarregados por conta da dupla função. Já sobre a pergunta 3, ele diz: "Problema com passageiro, problema com troco, cobrar e dirigir, estresse com o trânsito, hoje em dia ninguém respeita mais nada, motorista de ônibus não é bem visto pelas pessoas e nós somos tratados como ninguém, como um lixo. Mas o maior problema ainda é o trânsito. ". Em relação a segurança no trabalho, ele relata que já foi assaltado diversas vezes, já passou por tiroteios e não se sente seguro no seu trabalho. Apesar de tanto tempo de profissão, ele nunca teve nenhum problema causado pelos desgasto da profissão, mas diz tomar medidas para evitar problemas de saúde: "procuro me alimentar bem, sei que a profissão causa muito problema de coluna e procuro me cuidar, faço exercício em casa. ". Ele considera que seus direitos trabalhistas não são respeitados pela empresa, citando que as horas extras trabalhadas não são pagas e não respeitam os horários. A pergunta 7 teve uma resposta bastante curta: "Não dão suporte nenhum". Sobre a pergunta 8, ele acha que "volta do cobrador diminuiria muito o estresse e a pressão ".

\section{Entrevista 22}

O motorista está a apenas 4 meses exercendo essa profissão, e esse fator pode ter contribuído para ele não demonstrar insatisfação em relação as suas condições de trabalho. Ele diz que as vezes se sente sobrecarregado por conta da dupla função, e sua média de horas trabalhadas por dia é de apenas 8 horas, baixa em comparação à média dos entrevistados por essa pesquisa. Ele diz que não enfrente problemas no seu dia-a-dia de trabalho, dizendo ser " tranquilo ". Sobre a segurança no ambiente de trabalho, ele diz nunca ter sofrido nada que tentasse contra sua vida e que lida muito bem com as pessoas. $O$ entrevistado diz não ter tido problemas de saúde por conta da sua profissão, e considera que a empresa se preocupa com seus direitos trabalhistas e com a sua saúde "Atualmente não tenho o que reclamar da empresa ". Sobre a pergunta 8 , ele acredita que a volta dos cobradores "melhoraria bem ". O entrevistado pode ter tido medo de responder de forma verdadeira as perguntas, por achar que é uma avaliação da empresa em que ele trabalha, e poderia resultar em uma possível demissão.

\section{Entrevista 23}

O entrevistado trabalha a 13 anos como motorista de ônibus urbano. Considera sobrecarregado por conta da dupla função. Ele tem uma média de trabalho baixa, 8 a 9 horas por dia. Em relação a pergunta 3 ele diz que enfrenta problemas com troco, transito e 
pessoas mal-educadas e estressadas que descontam os problemas nos motoristas. Perguntado se ele já sofreu algum tipo de risco no ambiente de trabalho, a variável região se mostra, novamente importante: "Assalto na Av. Brasil, colocaram faca no pescoço, arma. Por causa da violência da cidade é difícil se sentir seguro, na região que eu trabalho pela zona sul é mais tranquilo, mas quando vou para outras regiões, como tijuca e o Borel, tomo mais cuidado. ". Apesar de nunca ter tido problemas de saúde relacionado a sua profissão, ele diz que: "É muito comum em motoristas de ônibus problemas sérios de coluna ", e evita esses problemas trabalhando com uma postura boa. Ele diz que, a empresa que ele está atualmente, respeita bastante os direitos trabalhista, mas tem muitas que não respeitam. A pergunta 7 ele diz que só se eles (motoristas) pagarem, caso contrario a empresa não paga. Sobre a pergunta 8, ele pensa um pouco para responder, e diz: "Facilitar o troco ou voltar a função do comprador e educação das pessoas. ".

\section{Entrevista 24}

O motorista tem 6 anos de profissão, e faz uma média de 8 a 9 horas de trabalho por dia.Ele se diz muito sobrecarregado por conta da dupla função. O único problema que ele destaca, que enfrenta diariamente, são os ficais "por causa do horário que eles querem que a gente cumpra e com o trânsito fica difícil ". Apesar de nunca ter passado nenhum risco à sua vida no seu ambiente de trabalho, ele diz que muitos colegas de profissão já foram assaltados, e por isso não se sente seguro. Mesmo não tendo sofrido com nenhum problema de saúde relacionado ao seu trabalho, ele faz uma reclamação em relação aos assentos dos ônibus: "os bancos dos ônibus que eu trabalho o estofado e o amortecedor não estão bons, precisam de bancos novos “. Ele diz que a empresa fornece um plano de saúde que é descontado do salário dos motoristas e existe uma área medica da empresa que "certifica os atestados médicos e se os motoristas têm condições físicas para dirigir ". Sobre a pergunta 8 , ele considera que os ficais deviam ser mais educados em relação a cobrança com horários e diminuir as horas extras que eles são obrigados a cumprir. Quando perguntado sobre seus direitos trabalhistas (pergunta 6), ele diz: "Não".

\section{Entrevista 25}

O motorista tem 2 anos de profissão, e apesar de mostrar-se com vontade de responder o questionário e contribuir com a pesquisa, ele parecia estar com pressa e acabou dando respostas curtas. O motorista faz uma média de 9 horas de trabalho por dia. Sobre se sentir sobrecarregado por conta da dupla função, ele diz:"seria mais confortável só dirigir ".Sobre a pergunta 4, ele diz: "Já, risco de assalto, tumulto com o pessoal que vai para a praia. Não me sinto seguro. “. O motorista considera que seus direitos trabalhistas não são respeitados pela empresa, e cita a dupla função como exemplo. E perguntado sobre o que poderia ser melhorado para tornar sua rotina de trabalho menos estressante, ele cita acabar 
com a dupla função. As perguntas 3, 5 e 7 não foram mencionadas pois o entrevistado deu uma resposta muito curta em ambas as perguntas: "Não". 